IZA DP No. 7142

The Effects of the State Sector on Wage Inequality in Urban China: 1988-2007

Qingjie Xia

Lina Song

Shi Li

Simon Appleton

January 2013 


\title{
The Effects of the State Sector on Wage Inequality in Urban China: 1988-2007
}

\author{
Qingjie Xia \\ Peking University \\ Lina Song \\ University of Nottingham and IZA \\ Shi Li \\ Beijing Normal University and IZA \\ Simon Appleton \\ University of Nottingham and IZA \\ Discussion Paper No. 7142 \\ January 2013 \\ IZA \\ P.O. Box 7240 \\ 53072 Bonn \\ Germany \\ Phone: +49-228-3894-0 \\ Fax: +49-228-3894-180 \\ E-mail: iza@iza.org
}

Any opinions expressed here are those of the author(s) and not those of IZA. Research published in this series may include views on policy, but the institute itself takes no institutional policy positions. The IZA research network is committed to the IZA Guiding Principles of Research Integrity.

The Institute for the Study of Labor (IZA) in Bonn is a local and virtual international research center and a place of communication between science, politics and business. IZA is an independent nonprofit organization supported by Deutsche Post Foundation. The center is associated with the University of Bonn and offers a stimulating research environment through its international network, workshops and conferences, data service, project support, research visits and doctoral program. IZA engages in (i) original and internationally competitive research in all fields of labor economics, (ii) development of policy concepts, and (iii) dissemination of research results and concepts to the interested public.

IZA Discussion Papers often represent preliminary work and are circulated to encourage discussion. Citation of such a paper should account for its provisional character. A revised version may be available directly from the author. 
IZA Discussion Paper No. 7142

January 2013

\section{ABSTRACT}

\section{The Effects of the State Sector on Wage Inequality in Urban China: 1988-2007}

This paper examines the effects of state sector domination on wage inequality in urban China. Using Chinese Household Income Project surveys, we conduct two exercises: with quantile regression analysis, we identify wage gaps across the distribution and over time; and we employ the Machado and Mata (2005) decomposition to investigate how urban wage inequality was affected by the changes in wage structure and employment share of the state sector. We find that since the radical state sector reforms designed to reduce over-staffing and improve efficiency since the late 1990s, urban wage gaps were narrowed due to the reduction of employment share in the state sector; the wage premium of the state sector in comparison with the non-state sector increased significantly; and changes in the wage structure of the labour market caused the rise in urban wage inequality.

JEL Classification: J31, J42, O15, P23

Keywords: China, state sector, wage inequality, quantile regression, counterfactual analysis

Corresponding author:

Qingjie Xia

School of Economics

Peking University

Beijing 100871

China

E-mail: qingjie.xia@pku.edu.cn 


\section{Introduction}

Although the Chinese economy has been transformed immensely, it is still dominated by the state bias towards the public service sector and state-owned enterprises. The bias is indicated by the share of state sector employment and related wage setting. In the past decade, there has been widespread concern that industrial wage gaps, particularly between the state and non-state sectors, have been increasing in China.

Industrial wage differentials could exist even in a perfectly competitive market economy. This may be due to the fact that wages are normally higher in high-tech and capital intensive industries than that in low-tech or labour intensive industries ceteris paribus. If the wage gaps are substantial under this circumstance, there is no need to directly restrict the pay in the highly paid industries instead, the government could tax high salaries and set a minimum wage. China is arguably different. The transition of Chinese economy is characterized by a still less well functioning market system and strong government intervention. The state-bias has been reinforced with a launch of a series of economic policies in China starting from mid 1990s and being reinforced since 2002 .

State-dominated policies have allowed the Chinese state to monopolize prices, retain monopolistic profit and set up higher wage payments to state sector employees than their marginal product of labour or market clearing price. In fact, the central government of China from 2002 has established tight control of resource allocation, allowing state sector monopolization of key economic sectors (finance and banking, transportation and communication, and energy sector) and has created the taxation allocation system between central and local governments. This has strengthened central control over resource income (apart from local land), but left insufficient tax income for local governments. Those economic policies have safeguarded the political goals of relentless pursuit of GDP growth and this has continued up to the change of party leadership in 2012 (Zhang, 2012).

The aims of this paper are to examine whether state-biased policies have trigged the rise in urban wage inequality over time, and whether across the distribution, wage gaps are affected by the state sector domination. We begin by providing a brief overview of the change in China's state power. The power of the Chinese state sector has differed in strength since the economic reform. Power was decentralized in the first decade of the reforms, but then strengthened and made more centralized since the mid-1990s. The relationship between the central government and the state sectors affiliated to it during this time may have affected the payment of its employees.

Prior to the economic reform, wages were institutionally determined according to a national system of grades, scales and seniority, with education and skill receiving little reward (Knight and Song, 1993, pp. 221-239; Zhang et al. 2005). From 1981, and in particular after 1986, the Chinese government allowed state owned enterprises (SOEs) to implement flexible pay schemes according to their profitability (Dai, 1994). Although initially the floating pay or bonus was not allowed to be more than 5\% of an SOE's total wage expenditure, this limit was gradually abolished (Meng, 2000, p. 83). The SOE reform of 1986 allowed larger pay differentials within each SOE, but it was difficult to monitor workers' productivity; therefore, floating wages or bonuses were distributed equally among workers (Meng, 2000, p. 83). Because of the soft budget constraints and no requirement to accept business risk, the objective of SOE managers was not maximization of profits but maximization of the welfare of SOE workers in terms of wages and bonuses. Sometimes, bank loans were used to pay large bonuses 
when the SOE made a loss (Walder, 1987, 1989). In fact, the SOE managers were also incentivized to raise the pay for their workers because the Chinese government had been restricted the pay gap between the SOE managers and SOE workers. The government decreed that the pay gap between the SOE managers and the average wages of SOE workers be not more than 2-3 fold even for those profit-making SOEs in the period from 1986 to 1992 (Chen et al. 2005). Based on 1985-1992 firm data, Meng (2000, p. 107) found that retained profits were the main determinant of wages in SOEs, whereas in private firms, it was the productivity of workers that determined pay. Therefore, with the exception of frequent increases in bonuses and subsidies of all types, ${ }^{1}$ the wage-setting mechanism of SOEs was broadly unchanged until the late 1990s when the radical SOE reform was implemented.

After Deng Xiaoping's southern tour in 1992, China's reform and marketization accelerated. A series of reform measures were carried out, such as abolishing the double-tract price system, ${ }^{2}$ unifying the tax regime and tightening credit. The most radical reform was the mass retrenchment of superfluous workers and retaining larger SOEs while disbanding smaller ones. There had been serious over-manning and efficiency problems in the SOE sector; were it not for the bank loans and financial subsidies from the state budget, many SOEs would have long been bankrupt. ${ }^{3}$ The implementation of the new reform measures exacerbated the difficulties encountered by those loss-making SOEs; for example, SOEs had to pay market prices for key resources, faced the same value-added taxes as non-state firms, and could not rely on bank loans to pay bonuses and other subsidies to their workers. Confronted with the ever-increasing number of loss-making SOEs and an ever-rising heavy budget burden caused by subsidizing SOEs, the Chinese government determined to reform the 120 thousand strong SOEs. The SOE reform was trialed in 1994 and finally implemented in 1997. A consequence of this was that the number of retrenched SOE workers reached 28 million, accounting for half of the SOE workforce (State Council News Office, 2004), and the number of SOEs was reduced (by 74\%) from 120 thousand in the mid-1990s to 32 thousand in 2004 (Naughton, 2007, p. 313). A key part of China's SOE reform was to transform the remaining SOEs, which are profitable and monopolistic with strategic importance for the country's economy, into modern market-oriented enterprises. The reform and restructure of SOEs was followed by soaring wages and bonuses in the SOE sector (see Tables 1-3). Even in the period of mass retrenchment, there was a pay rise for those still-employed SOE workers (Appleton et al. 2005; Bai et al. 2006). SCDR (2007) reported that the pay gap between the monopolistic SOEs and other enterprises has been increased largely in the period of 1990-2005.

The creation of a State Asset Supervision and Administration Commission (SASAC) in June of 2003 marked a significant change over the state administration of SOEs. One of the major changes is the total wages and salaries contract regime, by which in each year SASAC will negotiate with each of the centrally-controlled SOEs over the amount of wages and salaries for next year. The total wages and salaries contract regime effectively restrains wage costs and unreasonable pay rises of SOE workers. However, SOEs are reluctant to employ new workers because of the constraint on total wages and salaries. This is one the reason why the employment share of SOEs further been reduced in the period from 2002 to 2007. SOEs own

\footnotetext{
${ }^{1}$ The share of bonuses in the annual earnings of SOE workers increased from $2.4 \%$ in 1978 to $23.3 \%$ in 1993 , and that of all other subsidies rose from $6.5 \%$ to $25.1 \%$ in the same period (Meng, 2000, pp. 84).

${ }^{2}$ After having produced what the state demanded according to the planned prices, SOEs can sell their products on market according to market price; likewise, after having sold the planned quantity of grain to the state at the state procurement price, the rural household can trade their agricultural products on free market.

${ }^{3}$ Roughly $40 \%$ of the large and middle-sized SOEs were making loss in 1991 (Zhu Rongji, 2011, Vol. 1, pp. 15), the number of loss-making SOEs accounted 43\% of them and the total losses reached RMB 88.3 billion in 1995 (Zhou, 1996), in the middle of 1990s on the whole the middle and small sized SOEs were making loss (Naughton, 2007, pp. 302), in 1996 the share of SOEs' profit in China's GDP is almost zero (Naughton, 2007, pp. 304).
} 
almost the whole of the assets of the country and this asset base has been increasing all the time, despite the shrinking employment share. Additionally, the implementation of an annual salary system for managerial staff in the SOEs has resulted in the enlargement of pay gap within SOEs, for instance, the annual compensation for SOE managers is 9-10 times higher than the average annual wages of SOE workers (Liao et al. 2006; Bai, 2008), and Chen et al. (2005) found that the position-related consumption of SOE managers was more than ten times their annual salary.

As for the public service sector, the 1993 reform of pay rules for civil servants allowed regions to set up their own extra-pay scheme, which related the rise in salaries of regional civil servants to local economic growth. In other words, the reform sanctioned an arrangement under which provincial governments could set the salaries for their own civil servants according to their own budgets. Since then, pay differentials for civil servants have gradually been getting larger between provinces or between government agencies in the same region (Dai et al., 2005; Liu, 2006). In the period from 1998-2002 the pay for civil servants and other public sector workers had been raised three times (Zhu Rongji, 2011, vol. 4, p. 482). Furthermore, the pay for civil servants is higher than that in SOEs, collective enterprises and private firms (Dai et al., 2005). It was for these reasons that Jinglian Wu (2006), argued that the main causes of the rapid growth in income inequality in China were corruption and monopolistic state-owned industries.

We therefore hypothesize that the high pay in the public sector and monopolistic SOEs is one of the forces responsible for the increase in the urban wage gap. To test this hypothesis, we employ the 1988, 1995, 2002 and 2007 China Household Income Project (CHIP) urban household survey data, and Machado and Mata's (2005) parameterized counterfactual decomposition method based on multiple quantile regressions to identify the effect of the change in pay structure and employment shares in the public sector and SOEs on urban wage inequality.

The rest of the paper is structured as follows. In Section 2, we introduce the data and econometric methods. Sections 3 and 4 give the regression results and decomposition of wage income inequality respectively. Section 5 presents the summary and conclusions.

\section{Data and Methods}

\subsection{Data}

We use urban household survey data from the China Household Income Project (known as CHIP data) for 1988, 1995, 2002 and 2007 The survey samples were randomly selected from the larger annual national household survey conducted by the National Bureau of Statistics. The subsamples cover 10 out of 31 provinces in 1988, 11 in 1995, 12 in 2002 and 9 in 2007. The questionnaires were designed by a team of international scholars and obtained more detailed information than those in the official household surveys, particularly with respect to the measurement of income and labour issues.

For the cross-sectional analysis, we construct a real wage variable covering bonuses, income-in-kind, and price subsidies, regional allowances and income from second jobs. ${ }^{4}$ With

\footnotetext{
${ }^{4}$ Our wage variable, although fairly comprehensive, does exclude some non-monetary benefits such as pension accruals, health insurance and housing. The contributions of these variables may vary under differing forms of ownership and over time. Nominal wages were converted into real wages by deflating by regional urban CPIs.
} 
respect to differential costs of living over time and between regions, we adjusted all wage incomes of all years based on urban consumer price indices published by China's National Statistical Bureau, and using 2002 prices as constant. Results from these surveys are in Griffin and Zhao (1993), Riskin et al. (2001), Li and Sato (2006) and Gustafsson et al. (2008).

Our analysis in this paper covers households with urban registration (hukou). The reasons to exclude rural-urban migrant households are as the following: first, there were no systematically conducted rural-urban migrant household surveys conducted in 1988 and 1995; the lack of earlier data of migrant households could not serve the comparative purpose set in this paper, although this omission has increased over time with the sharp increase in ruralurban migration during the sample period. Second, in estimating the wage functions of workers, urban and rural-urban migrant workers do not share the same characteristics, in particular, a large proportion of migrant labour force in urban area are self-employed, or engaged in the informal jobs with no regular wage income. If we only draw those who are wage earners from migrant surveys and combined them with the urban labour force, the sub-sample of migrant wage earners could be subject to sample selection bias. Most importantly, our goal in this paper is to investigate the determinants of wage inequality highlighting the effects of ownership and industrial sectors over time. Therefore confining our analysis to the subpopulation holding urban hukou allows us to examine the institutional causes which have increased urban wage inequality over the period of 20 years.

\subsection{Methods}

We employ the quantile regression method to estimate the extended Mincerian earnings function (Mincer, 1973). Let $Q_{d}\left(w_{\mathrm{it}} \mid \mathrm{X}_{\mathrm{it}}\right)$ for $\theta \in(0,1)$ denote the $\theta^{\text {th }}$ quantile of $(\log )$ wages $w$ of an individual $i$ in year $t$ for given explanatory variables, $X$. For each year, we model these conditional quantiles separately by:

$$
Q_{\theta}\left(\ln W_{i t} \mid X_{i t}\right)=X_{i t}^{\prime} \beta_{t}(\theta),
$$

where $\beta(\theta)$ is a vector of quantile coefficients, and $X$ is a vector of explanatory variables. The coefficients are estimated following Koenker and Bassett's (1978) quantile regression estimator. In practice, we run 19 quantile regressions (from quantile points 0.05, 0.10, 0.15, ..., 0.95) for each of the four rounds of cross-sectional data. ${ }^{5}$ Afterward, we plot a curve for the 19 coefficients on the dummy variable (with 1 indicating a worker employed by the state sector and 0 by the non-state sector) against the 19 quantile points of the wage distribution for each year. From these curves we can observe the wage premium of the state sector versus the non-state sector across the entire wage distribution over time.

The quantile regression has a number of advantages over conventional ordinary least squares (OLS) regressions. Most importantly, it provides a complete representation of the conditional distribution of wages whereas the conventional regression focuses only on the conditional mean. ${ }^{6}$ This is particularly crucial for understanding inequality because a standard regression focuses only on central tendency. Furthermore, the quantile approach makes it possible to test whether the effects of some determinants of wages on workers higher up in the conditional

\footnotetext{
${ }^{5}$ The distance between any two quantile points is 0.05 .

${ }^{6}$ Other advantages of the quantile approach are that it is less sensitive to outliers, more robust to departures from normality (Koenker and Bassett, 1978) and has better properties in the presence of heteroscedasticity (Deaton, 1992).
} 
wage distribution are different from the effects on those lower down. For this, we can examine whether the wage premium of the state sector varies at different points of the conditional wage distribution. The quantile approach recognizes the unobserved heterogeneity of workers and thus generates a richer picture of the determinants of wages.

Quantile regressions are far from perfect. Outliers and skewed distributions (often observed in large-scale cross-section household survey data) make quantile regression residuals deviate from the independent and identical distribution (i.i.d.) assumption. If the i.i.d. assumption for the regression residuals no longer held, the statistical inference from the regression results would be invalid (Hao and Naiman, 2007, pp. 44-47). To circumvent this technical difficulty, the bootstrap method is applied to the quantile regressions (Kocherginsky et al., 2005). As bootstrap quantile regressions do not need the i.i.d. assumption, they are more robust and practical. For this reason, bootstrap quantile regressions are employed in this paper.

Some care must be taken in interpreting the results of the quantile analysis, because they pertain to conditional quantiles, not unconditional ones. Thus, a worker at a high-wage quantile would be one who receives high wages relative to his/her values of the observed determinants of wages, $X$, rather than simply a high-wage worker per se. Another way of saying this is that a worker at a high-wage quantile will tend to have favorable unobserved determinants of wages. This shows the difficulty in interpreting the results. As some determinants of wages are unobserved, it is not clear exactly what they are. They could include measurement error, for example, or random factors (a worker's good fortune in chancing upon a high-paying position). However, there is some interest in these unobservables; for example, unobserved personal characteristics affecting earnings are often labeled "ability" in the theoretical literature (although they may also encompass determination, ambition and factors such as personal appearance). Unobserved characteristics of a job may also be interesting; for example, we do not observe firm size or profitability, but rent-sharing theories imply these may have significant effects on earnings. In our exposition, for brevity, when describing the patterns in our findings, we often refer to high quantiles unconditionally as representing high-wage workers-as is common in the applied literature; however, this is an oversimplification and a more nuanced interpretation focusing on unobservables is often invoked when trying to explain our results.

One of our main purposes of using quantile regressions is to study the evolution of pay differentials between the state and non-state sectors for the period from 1988 to 2007. To this end, we control for the variables that apply across all four years of CHIP urban household survey data in the earnings function (1). In detail, these variables are workers' schooling, experience and experience squared, dummy variables for sex, Communist Party membership, non-Han Chinese ethnicity, job characteristics in terms of occupations and industrial sectors, and provincial dummies. The variable of interest in this paper is a dummy variable identifying a worker's employer with 1 indicating the state sector and 0 the non-state sector.

The focus of this paper is on exploring the effect of the state sector's wage structure and employment share on urban wage inequality for the period from 1988 to 2007. For this reason, we employ Machado and Mata's (2005) method (MM method hereafter) to decompose changes in wage inequality into changes attributable to two sources. One is the change in wage structure in terms of the coefficients on the various explanatory variables. The other is the change in the distribution of explanatory variables, i.e., the change in workers' personal and productive characteristics, and in job characteristics. In detail, following Machado and Mata (2005), if $\alpha($.$) are summary statistics for wages — such as the Gini coefficient-then we can$ decompose the changes in $\alpha$ as follows: 


$$
\begin{aligned}
& \alpha(f(w(1)))-\alpha(f(w(0))) \\
= & {[\alpha(f *(w(1) ; X(0)))-\alpha(f *(w(0)))]+} \\
& {[\alpha(f *(w(1)))-\alpha(f *(w(1) ; X(0)))]+\text { coefficients } } \\
& \alpha\left(f_{\text {covariate }}^{*}\right.
\end{aligned}
$$

where $f(w(t))$ denotes the estimator of the marginal density of $w$ (the log wage) at $t$ based on the observed sample $\left\{w_{i}(t)\right\}, f^{*}(w(t))$ denotes the estimator of density of $w$ at $t$ based on the generated sample $\left\{w_{i}^{*}(t)\right\}$, and $t=0,1$. The counterfactual densities are denoted by $f^{*}(w(1)$; $X(0)$ ), for the density that would result in $t=1$ if all covariates had their $t=0$ distributions, $f^{*}\left(w(1) ; X^{i}(0)\right)$, for the wage density in $t=1$ if only $X^{i}$ (part of the covariates) were distributed as in $t=0$.

Furthermore, the contribution of an individual covariate $x_{\mathrm{i}}$ to the total wage inequality could be measured by looking at indicators such as:

$$
\alpha\left(f^{*}(w(1))\right)-\alpha\left(f^{*}\left(w(1) ; x_{i}(0)\right)\right) .
$$

Along the lines of MM method, we are able to counterfactually measure the contribution of an individual coefficient $\beta_{\mathrm{i}}$ to the change in wage inequality by observing:

$$
\alpha\left(f *\left(w(0) ; \beta_{i}(1)\right)\right)-\alpha(f *(w(0))),
$$

where $f^{*}\left(w(0) ; \beta_{i}(1)\right)$ denotes the estimator of the density of $w$ with all covariates at period 0 and all coefficients, apart from $\beta_{\mathrm{i}}(1)$, from period $0 ; \beta_{\mathrm{i}}(1)$ denotes the coefficient of $x_{\mathrm{i}}$ from period 1 . With formula (4), we then counterfactually analyze the change in the wage inequality and wage gap caused by specific changes in the pay structure, such as changes in the returns to education.

In essence, Machado and Mata's counterfactual decomposition is an extension of Oaxaca's (1973) decomposition for quantile regressions. ${ }^{7}$ A key exercise of the MM method is to obtain the generated sample $\left\{w_{i}^{*}(t)\right\}$. To obtain $\left\{w_{i}^{*}(t)\right\}$, one first needs to estimate $n$ quantile regression coefficients $\hat{\beta}^{t}\left(\theta_{i}\right)$ (where $\theta_{i}$ denotes the quantile point), and then generate a random sample of size $n$ with replacement from the rows of $X(t)$ denoted by $\left\{x_{i}^{*}\right\}_{t=1}^{n}$, and finally get $\left\{w_{i}^{*}(t)=x_{i}^{*}(t)^{\prime} \hat{\beta}^{t}\left(\theta_{i}\right)\right\}_{t=1}^{n} \cdot{ }^{8}$ For details, the reader is referred to Machado and Mata (2005).

Finally, because China's economic transition has occurred gradually, the counterfactual decomposition is implemented period by period. In detail, these periods are 1988-1995, 19952002 and 2002-2007, based on the availability of the CHIP data. The same explanatory variables were applied in all the four years' earning functions.

\footnotetext{
${ }^{7}$ As is well known, there is a potential index number problem with such exercises.

${ }^{8}$ According to Machado and Mata (2005), one needs to randomly draw $\theta_{\mathrm{i}}$ of sample size $n$ from $\theta[0,1]$. However, in practice, we only take 999 quantile points with equal distance from the uniform distribution on [0,1] by following Albrecht et al. (2003) and Rica et al. (2008). In other words, we estimated 999 quantile regressions for quantile points $0.001,0.002,0.003, \ldots, 0.999$ on $[0,1]$ for the earnings function for each of the four years.
} 


\section{Results from Quantile Regressions}

\subsection{Wage gaps between the state and non-state sectors}

The change of urban wage over time is reported in Table 1 . The Gini coefficient of urban wage income increased sharply from 0.237 in 1988 to 0.345 in 1995, and remained unchanged in 2002, but rose to 0.439 in 2007. The Lorenz curves of wage income during these four years show the same trend (Figure 1). The 90/10 wage ratio increased sharply from 2.82 in 1988 to 6.43 in 2007. The wage gaps in the non-state sector are larger than those in the state sector (public service sector and SOEs), but the difference between them is diminishing (Table 2). Finally, the wage gaps within each sector and each subsector increased continuously during this period.

Figure 2 exhibits raw (unconditional) daily wage gap curves between the state sector (comprising the public service sector and SOEs) and the non-state sector based on percentile points, ranged from low to high. In general, pay in the state sector is higher than in the non-state sector. In 1988, for the $10^{\text {th }}$ percentile point, the wage in the state sector is 1.5 times that in the non-state sector, but this ratio decreases to 1.1 for the $90^{\text {th }}$ percentile point. In 1995 , the inverse relationship between the wage gap of the state and non-state sectors and the wage level strengthened. The ratio of wages in the state and non-state sectors for the $10^{\text {th }}$ and $90^{\text {th }}$ percentiles increased to 1.9 and 1.2 respectively. Although the state sector still paid more than the non-state sector in 2002, the gap is smaller than that for 1995 below the $35^{\text {th }}$ percentile of the wage distribution, whereas the wage gaps for these two years above the $35^{\text {th }}$ percentile are roughly the same. In 2007, the wage gap between the state and non-state sectors is close to that for 1988 in the lower part of the wage distribution and close to that for 2002 in the rest of the wage distribution.

\subsection{Wage gaps within the state sector of China}

Another trend worth discussing is the change in wage gaps within the state sector over time and cross the distribution. In this paper, the state sector consists of two subsectors: public service sector and the state owned enterprises. The former covers government offices and state-funded institutions such as schools, universities, hospitals, etc. The latter is the SOE sector. Therefore, before examining the wage gap between the state sector and non-state sector, it is necessary to investigate the pay differential between the public sector and SOEs.

As a result of mass retrenchment within the state sector since 1990s, the share of employment in the public service sector rose from 30\% in 1995 to 32\% in 2007, whereas that in the SOEs fell sharply from 51\% in 1995 to 34\% in 2002 and further to 18\% in 2007 (Table 4). When the labour force within the state production was reduced while that in the service sector was not affected, would this affect wage inequality with the state sector? To be specific, within the state sector, were wages was more equally distributed between the two types of employees? What was the trend of wage distribution within the state sector during the reform decades?

To determine whether there is any pay differential between the public sector and SOEs, we employ CHIP urban household survey data for 1995, 2002 and 2007 in which the public sector and SOEs can be identified by exploring the pay gap between these two subsectors. ${ }^{9}$ The OLS

\footnotetext{
${ }^{9}$ The ownership variables include public sector, collective enterprise, foreign-owned and joint-venture enterprises, private sector and others with SOEs as the reference variable. Other variables such as workers' sex, Communist Party membership,
} 
regression results reveal that the pay in the public service sector was 8\% higher than that in SOEs in 1995; however, this pay gap drops to 5\% in 2002, and to -2\% in 2007 although it is statistically insignificant. During this period, one important policy initiated which might have altered the wage distribution between the two sub-sectors. A more centralized budgeting system was launched in 1994, under which the cost for teachers, medical service workers and all public service sector workers are funded by the central government budgetary system. Among those paid by the central public budgets include the very low paid country-side teachers and those state CEOs of SOES whose annual payments could reach millions.

Figure 3 plots the premium paid to public service workers over those in SOEs. In 1995, the premium is positive, but generally falls in size as we move up the conditional wage distribution (the exception is the spike at the 95th percentile). In 2002, there is a similar pattern except that the gap falls so much that it becomes negative and for the top 23 percentiles, SOE workers are paid more than public sector workers. In 2007, the pay in the public service sector is generally lower than that in SOEs except for the top 23 percentiles which are higher than that of 2002 level. This indicates that SOE workers are better paid than those in the public service sector for but the top quintile. There is thus a reversal payment structure between the two subsamples between the early period and the year of 2007. After 2002, state owned enterprises paid higher wages to most of their workers than did the public service sector, the exceptions being at the top end of the distribution.

\subsection{Evolution of the wage premium of state sector versus non-state sector}

Figure 4 presents the evolution of the wage premium curves for the state sector over the non-state sector. For 1988, the wage premium decreases as the conditional wage level increases, with the largest premium of $24 \%$ occurring at the fifth percentile of the wage distribution, $14 \%$ at the median percentile and $8 \%$ at the $95^{\text {th }}$ percentile. These results are reinforced by 1995 data, in that the wage premiums of the state sector versus non-state sector at the fifth, median and $95^{\text {th }}$ percentiles of the wage distribution were $34 \%, 24 \%$ and $17 \%$, respectively. This raises several questions. What caused the pay of the state sector to be significantly higher than that of non-state sector in 1988 and 1995? Why was this wage premium further raised in 1995 compared with 1988? And finally, why does the wage premium fall as the wage level increased?

The history of SOE reform might shed light on the above questions. The Chinese government started allowing SOEs to implement flexible pay schemes according to their profitability in the early 1980s. The objective of SOE managers was not maximization of profits but maximization of the welfare of SOE workers in terms of wages and bonuses, because there are the soft budget constraints and no requirement of bearing business risk and that the pay gap between a SOE managers and the average SOE worker should not be more than 2-3 fold. Additionally, retained profits were the main determinant of wages in SOEs, whereas in private firms, it was the productivity of workers that determined pay. Therefore, with the exception of frequent increases in bonuses and subsidies of all types, the wage-setting mechanism of SOEs was broadly unchanged until the late 1990s when the radical SOE reform was implemented. This problem, which resulted from poor institutional design, meant that the pay in SOEs was higher than that in private firms and that the magnitude of this pay differential increased in the period from 1988 to 1995.

ethnicity, occupation, industrial sectors, provincial dummies are the control variables. 
Floating wages or bonuses, which were permitted since the early 1980s, were distributed equally among workers within each SOE because of the difficulty to monitor workers' productivity. By contrast, the wage of a worker in a private firm was determined by his/her marginal product. Therefore, we expect that wage inequalities will be much larger in private firms than in SOEs, which this study confirms (Tables 2 and 3). Pay in SOEs is reasonably equally distributed among workers, whereas wage inequalities in private firms are large, which accounts for the wage premium of the state sector being larger than that of the non-state sector in the lower part of the wage distribution and smaller in the upper part. Chamberlin (1994) found that the wage premium of trade union members is higher in the lower part of the wage distribution. This suggests that the SOEs in China played a similar role to that of trade unions in the US in terms of wage negotiations; that is, the SOEs are more effective in protecting lower-wage workers.

Because of the change in political atmosphere after 1992, China's reform and marketization accelerated. The radical SOE reform resulted in a sharp fall of the employment share of SOE sector and less but strengthened those SOEs that were profitable and monopolistic with strategic importance for the country's economy. Other reform measures also have had a significant impact on SOEs, such as abolishing the dual pricing system forced SOEs to pay market prices for key resources, unifying the tax regime caused SOEs to pay the same value-added taxes as other non-state firms, and tightening credit deprived SOEs of using bank loans to pay bonuses and other subsidies to their workers. Despite of these reform measures, surviving non-retrenched SOE workers shared the profits brought about by the improved efficiency of SOEs and public service workers enjoyed pay rise three times for the period from 1997 to 2002, as discussed in Sections of this paper. What effect did these reforms have on the wage-setting mechanism of SOEs? Figure 4 shows that the wage premium of the state sector versus the non-state sector declined to 1988 levels (in the first quintile and the fourth quartile, the premium was even less than that in 1988), and hence was much lower than that in 1995. What factors caused the 2002 wage premium to be so far below the 1995 level? After the Asian financial crisis in the late 1990s, the Chinese economy experienced deflation until around 2002. Additionally, the urban labour market was heavily flooded by the roughly 30 million retrenched SOE workers and the almost 100 million rural-urban migrants. ${ }^{10}$ Therefore, there existed no wage inflation pressure in the private sector. ${ }^{11}$ Any pay rises in the private sector were a consequence of productivity change that might be resulted from the unprecedented large-scale inflow of $\mathrm{FDI}^{12}$ and the improved competiveness of urban labor market. ${ }^{13}$ In summary, the fall of the wage premium of the state sector in 2002 relative to 1995 could only be the result of significant pay rises in the non-state sector during this period.

In 2007, the wage premium of the state sector was still less than that of 1988 over the first quintile of the wage distribution. However, for the second to fifth quintiles, the wage premium of the state sector for 2007 was higher than that in both 1988 and 2002, but lower than that in 1995.

\footnotetext{
${ }^{10}$ The number of rural-urban migrants dramatically soared from 15 million in 1990 to 98 million in 2003 (News Office of the State Council, 2004), and further to 145 million in 2009 (Ministry of Human Resources and Social Security, 2010). The reform of financial and banking sector aimed at solving bad loans resulted in sharp reduction of financial supports to rural industrial activities and hence large-scale closure of rural industrial enterprises, which in turn forced rural surplus labourers migrating to urban areas for employment (Huang, 2008).

${ }^{11}$ In contrast to the shrinking of the SOE sector, non-state sectors are significantly expanding. For example, the share of employment in urban areas created by the non-state sectors rose from 26\% in 1992 to $68 \%$ in 2001 and further to $78 \%$ in 2007 even without accounting for jobs being brought about by the rural-urban migrants (NSB, 1993, 2002 and 2008).

${ }_{12}$ Attracted by the huge market, cheap labour and high economic growth rate, tremendous amount of foreign direct investment flows to China so that China replaced America as the top recipient of FDI in 2003 (53 billion US dollars, OECD, 2004), the figure climbing to 90 billion US dollars in 2009 (Wen, 2010). The foreign-owned enterprises paid the much higher wages than domestic ones to recruit highly skilled and motivated workers (Appleton, et al. 2005; Xia et al, 2009).

${ }^{13}$ At the turn of the century, China's labor market had become more competitive than in the late 1980s.
} 
Furthermore, the wage premium of the state sector for 2007 is close to constant for the middle $50 \%$ of the wage distribution. However, for the fourth quartile, the wage premium of the state sector for 2007 decreases as the wage level increases. In general, the wage premium of the state sector increased significantly during the period from 2002 to 2007. What factors could have led to this result? The operating environment of the SOEs changed dramatically after 2002 with the completion of the abovementioned radical SOE reforms. The remaining SOEs were profitable and monopolistic with strategic importance to the country, such as banks, financial firms, telecoms, and aviation, railway and energy enterprises. According to the National Statistical Bureau, the growth rates of wages in the SOE sector and non-state sector were $14.12 \%$ and $12.76 \%$, respectively, during the period from 2002 to 2009, and the SOEs' wage premium relative to non-state firms increased from $0.30 \%$ in 2002 to $10.36 \%$ in $2009 .{ }^{14}$ Therefore, Wu (2006) speculated that the expanding wage inequality was caused by the monopolistic SOEs and corruption; Gu and Feng (2008), Yue et al. (2010) and Jia (2011), among others, also found that the pay gap between monopolistic SOEs and other enterprises is unacceptable.

\subsection{Reasonable and unreasonable components of the wage premium of the state sector versus non-state sector}

Following Yue et al. (2010), we also explore the extent to which the wage premium of the state sector versus non-state sector is reasonable. We estimate Oaxaca-Blinder decomposition ${ }^{15}$ on the dummy variable of being employed in the state sector in the extended Mincerian earnings function of this paper for the four rounds of the CHIP urban household survey. The purpose of this is to measure reasonable and unreasonable components of the wage premium of the state sector versus non-state sector.

The Oaxaca-Blinder decomposition based on OLS regressions shows that the unreasonable part of the wage premium of the state sector versus non-state sector was in the range of $43-44 \%$ for the years 1988, 1995 and 2002, but that it climbed to 81\% in 2007 (Table 5). Nevertheless, the unreasonable part of the wage premium of the state sector had been kept at roughly the same level for the period from 1988 to 2002 but shot up sharply in 2007. Yue at al. (2010) found that the unreasonable part of the wage premium of the monopolistic SOEs versus non-monopolistic firms is as high as $60 \% .{ }^{16}$ Recall that the wage premium of the public service sector versus SOEs decreased as the wage level increased in 1995 and 2002, whereas in 2007 the opposite occurs. As mentioned above, after the reforms, the remaining SOEs were profitable and monopolistic. These monopolistic SOEs could obtain favorable treatment from various government agencies and banks (such as easy credit, lower taxes, right to control

\footnotetext{
${ }^{14}$ The pay gap between the average wages of SOEs and the non-state sector calculated from the NSB report is somewhat different from that derived using the CHIP urban household surveys. The latter was based on randomly sampled urban household survey data. Therefore, it is closer to reality.

${ }^{15}$ In this paper, the Oaxaca-Blinder decomposition based on OLS regression and the multiple quantile regression is conducted using the downloadable STATA procedure "decomp". The STATA procedure "decomp" was written by Ian Watson, who closely follows Blinder's exposition and uses both his method and his terminology. We adopt the "decomp” procedure because it suits our objective. In the Oaxaca-Blinder decomposition of the pay gap between the state sector and non-state sector in this study, the wage structure of the non-state sector is decided by market competition, whereas the nonmarket factors play significant roles in the pay setting of the state sector. For example, in the state sector, a worker's political affiliation is an important determinant of earnings. In the monopolistic SOEs, monopolistic profit may increase the pay of the workers. Therefore, the wage premium of the state sector versus non-state sector is the result of positive discrimination. Thus, in the process of the Oaxaca-Blinder decomposition, the regression coefficients of the earnings function for the non-state sector should be set as the reference, and the characteristics of the state sector workers should be the weights in calculating the unexplained (or unreasonable) part of the wage premium of the state sector versus non-state sector. The reverse decomposition of the "decomp" procedure is required in this study.

${ }^{16}$ Because rural-urban migrants are covered in the CHIP urban household survey, we use Yue et al.'s (2010) Oaxaca-Blinder decomposition of the pay gap of monopolistic SOEs and others when the rural-urban sample are excluded.
} 
scarce resources), set monopolistic prices, harvest monopolistic profits and hence pay their workers' wages well above market prices. This could be the main factor that boosted the unreasonable part of the wage premium of the state sector versus non-state sector.

\section{Counterfactual Analysis: Effect of the Wage Structure and Employment Share of the State Sector on Urban Wage Inequality}

Having presented the wage gaps between the state sector and non-state sector and its evolution during the period from 1988 to 2007, we now provide findings revealing how urban wage inequality was affected by the change in the wage structure and employment share of the state sector (encompassing both the public service sector and SOEs). In so doing, we test our key hypothesis whether the high pay in the public service sector and SOEs have caused the rise in urban wage inequality. As stated in Section 2, the change in wage income inequality can be counterfactually decomposed by the change in the wage structure (the change in regression coefficients of the earnings function) and the change in workers' characteristics (the explanatory variables of the earnings function). Through this counterfactual decomposition, we can observe how the wage inequality was influenced by change in any part of the wage structure (any coefficient or any group of coefficients of the earnings function) or any explanatory variables. Here we focus on how the urban wage inequality was affected by the change in the state sector wage premium (regression coefficient of the dummy variable "state sector”) and the change in the employment share of the state sector.

For this exercise, we show how the Gini coefficient and various percentile ratios of the wage distribution. Table 6 reports how these were affected by the change in the regression coefficient of the state sector dummy, holding all other regression coefficients and all explanatory variables unchanged. Table 7 provides corresponding information on the impact of the change in employment share of the state sector, holding all other explanatory variables and all regression coefficients unchanged. The percentile ratios of the wage distribution presented are $90 / 10,75 / 25,90 / 50$ and 50/10. We carried out 10 rounds of counterfactual simulation and then averaged the results to give the indicators presented in the tables. The purpose of this averaging was to avoid the results being unduly affected by a single simulation result. In each round of the counterfactual simulation, we randomly selected 999 observations of the explanatory variables from the data for any particular year.

\subsection{The effects of the regression coefficient of the state sector on urban wage inequality and wage gap}

The effects of the regression coefficient of the state sector on urban wage inequality and wage premium are different in each transitional period of the Chinese economy. Compared with 1988, the sharp rise in the wage premium of the state sector versus non-state sector over the entire wage distribution (Figure 4) in 1995 resulted in an increase in urban wage inequality (Tables 6 and 7). For example, the Gini coefficient increased by 0.007 (if the MM decomposition is based on the 1988 wage structure and explanatory variables) or by 0.003 (if the decomposition is based on the 1995 wage structure and explanatory variables). The wage gap indicators such as the 90/10, 75/25 and 50/10 wage ratios also increased. However, the increase in wage gaps was asymmetric because the 50/10 indicator increased while the 90/50 indicator remained largely unchanged. This implies that the wage gap for workers with wages below the median level increased whereas the gap for workers above the median wage level was largely unaffected. 
The mass retrenchment of SOE workers commenced in 1995 and was complete by 2002. Compared with 1995, the fall in the wage premium of the state sector versus non-state sector in 2002 resulted in a fall in urban wage inequality. For instance, the Gini coefficient fell by about 0.013 (by 0.012 if the MM decomposition is based on the 1995 wage structure and explanatory variables, or by 0.014 if the decomposition is based on the 2002 wage structure and explanatory variables). The wage gap (in terms of 90/10, 75/25 and 90/50) also declined. Nevertheless, the fall in the wage gap for workers in the upper half of the wage distribution is larger than that for workers in the lower half.

During the period from 2002 to 2007, the remaining large monopolistic SOEs seized opportunities and achieved rapid growth, large monopolistic profits and steady pay rises for their employees, particularly their managerial staff. Consequently, the clear rise in the wage premium of the state sector versus non-state sector in the upper half of the wage distribution in this period caused an increase in urban wage inequality. The Gini coefficient increased by 0.003 (if the MM decomposition is based on the 2002 wage structure and explanatory variables) or by 0.002 (if the decomposition is based on the 2007 wage structure and explanatory variables). The wage gap indicators of 90/10, 75/25, 90/50 and 50/10 all increases, although high-wage earners received proportionately larger pay rises than low-wage earners.

\subsection{The effects of the employment share of the state sector on urban wage inequality and wage gap}

The MM counterfactual decomposition of the effect of the state sector premium is robust to whether beginning years or closing years are used as the reference points. By contrast, decompositions of the effect of the change in the employment share of the state sector are sensitive to the choice of reference year, particularly for the last two of the three periods (see Tables 6 and 7). For the period from 1988 to 1995, the employment share of the state sector remained largely unchanged so that the inconsistency is not apparent. However, the employment share of the state sector declined from $79 \%$ in 1995 to $65 \%$ in 2002 and further to $49 \%$ in 2007. If the counterfactual decomposition is based on the beginning year of the two periods from 1995 to 2002 and 2002 to 2007, the reduction in the employment share of the state sector results in a reduction in urban wage inequality using the Gini coefficient and urban wage gap in terms of 90/10 and 50/10. However, if it is based on the closing year of the two periods, the fall in the employment share of the state sector results in an increase in urban wage inequality.

To investigate the cause of this contradictory result, we extend the MM counterfactual decomposition to examine the effect of the change in the state sector employment share on urban wage inequality to all decile points of the employment share. We exemplify this simulated counterfactual decomposition method by using the 1995 wage structure and explanatory variables as the base. In fact, during the period from 1995 to 2002, the employment share of the state sector fell from $79 \%$ to $65 \%$. However, in the simulated counterfactual decomposition the employment share of the state sector in 1995 is kept constant, while assuming that the state sector's employment share can counterfactually be changed to $10 \%$, $20 \%, \ldots, 90 \%$. The same kind of counterfactual decomposition is implemented for 1988, 2002 and 2007.

Table 8 reports the simulation results of the counterfactual decomposition of the effect of variation in the state sector's employment share on urban wage inequality. From Table 8, when 
the employment share of the state sector is counterfactually changed to $10 \%, 20 \%, \ldots, 90 \%$ in each year, the difference between the counterfactual and factual urban wage inequality (the former minus the latter) changes from large to small and also from positive to negative. However, because the state sector has different employment shares in each of the four years, the transition from positive to negative in the difference between the counterfactual and factual urban wage inequalities in each year occurred at different intervals of the counterfactual employment shares of the state sector. It can be observed from Table 8 that the intervals of the counterfactual employment share of the state sector, in which the difference between the counterfactual and factual urban wage inequalities changes from positive to negative, decline along with the fall in the factual employment share of the state sector.

In addition, in the simulation of the counterfactual decomposition for each year, when the counterfactual employment share of the state sector is higher than the factual one in any particular year, the difference between counterfactual and factual urban wage inequality is negative. For the simulation results in Table 8, we assumed that the transition of the state sector's employment share is from factual to counterfactual, as in the decomposition results in Table 6. If we multiply every simulated number in Table 8 by “-1", we obtain the simulation results in reverse order-the transition of the state sector's employment share from counterfactual to factual, which is consistent with Table 7. Under this reverse order, when the state sector's counterfactual employment share is greater than the factual, urban wage inequality increases. Recall that the state sector's employment share has been decreasing since 1994. As a result, it is inevitable that contradictory results occur between the simulation results computed for the base year and those based on the current year for each of the two periods from 1995 to 2002 and 2002 to 2007.

In essence, the contradiction between the outcomes of the decomposition of the change in the employment share of the state sector versus non-state sector based on the beginning year and closing year's wage structure could be brought about by the difference in the wage structure of the beginning year and closing year of a decomposition period. China's economy and in particular her SOE sector had experienced drastic structural transformation in the periods from 1995 to 2002 and 2002 to 2007. Therefore, there should be fundamental change in the wage structure of the beginning year and closing year in each of the two periods. In addition, the MM counterfactual decomposition could be regarded as a kind of prediction method. Prediction is always made on the base year. Therefore, the MM decomposition of the change in employment share of the state sector versus non-state sector should be based on the beginning year's wage structure.

Taken together, whether the fall in the state sector's employment share leads to any change in urban wage inequality depends on the order of the counterfactual decomposition. Viewed as a prediction method, the counterfactual decomposition of how the change of employment share of state sector affects urban wage inequality should be based on the beginning year's wage structure for any period of interest. Taking this approach, the reduction of the employment share of the state sector in the periods from 1995 to 2002 and from 2002 to 2007 results in a decrease of urban wage inequality.

\section{Conclusions}

Conclusively, the SOEs per se, the sector's size and determinants of wage structure have been transformed considerably since the economic reform and in particular after the radical SOE reform of the mid-1990s. At the same time, the income inequality in urban China has 
drastically increased, for example, the Gini coefficient of urban wage income rose from 0.24 in 1988 to 0.44 in 2007 (Table 1). Therefore, a follow-up question is how China's urban wage inequality has been affected by the changes of employment share and determinants of pay structure in the SOE sector.

This paper examined the effect of change in the state sector's wage structure and employment share on urban wage inequality by employing CHIP urban household survey data from 1988, 1995, 2002 and 2007. As our methodology, we employed multiple quantile regressions and MM counterfactual decompositions. We also extended the MM counterfactual decompositions to all decile points in order to investigate the effect of change in the state sector's employment share on urban wage inequality. The results of the multiple quantile regressions and MM counterfactual decomposition revealed that after the radical SOE reform, the fall of employment share of SOE sector resulted in a decrease of urban wage inequality, but the wage premium of SOE workers and its unreasonable part increased significantly, which in turn led to an increase in urban wage inequality.

The state sector consists of the public sector and SOEs. The SOEs' share of total urban employment fell from 50\% in 1995 to 18\% in 2007, while the public sector's share remained at about 30\%. The results of the multiple quantile regressions suggest that pay in the public sector was higher than that in SOEs in both 1995 and 2002, but the gap decreased as one moved up the wage distribution. In 2007 there were no significant pay differentials between the public sector and SOEs, except that the pay in the latter was higher than that in the former for the top quintile. This implies that after 2002 there were larger pay rises in SOEs than in the public sector.

Before the SOE reforms, SOE managers had few credit constraints, little business risk and incentive to raise pay for workers, and the aim of SOEs was not the maximization of profits and total wealth, but rather the maximization of the pay and welfare of workers. Therefore, the main determinant of wages in SOEs was the amount of retained profit, rather than the productivity of the workers. The consequence of this former regime was that the wage premium of the state sector versus non-state sector increased considerably in the period from 1988 to 1995, which caused an increase in urban wage inequality.

During the SOE reform, the wage premium of the state sector was reduced temporarily, leading to a fall in urban wage inequality for the period from 1995 to 2002. However, the SOEs that survived the reform are large and monopolistic, characterized by opportunistic monopolistic profit and payment of high salaries. Therefore, since 2002, the rate of pay rises for SOE workers has not only been faster than that of the public sector but has also been faster than that of the private sector, which led to an increase in urban wage inequality. The Oaxaca-Blinder decomposition showed that the unreasonable part of the wage premium of the state sector versus non-state sector remained at about $44 \%$ until 2002, but then increased sharply to $81 \%$ in 2007. The monopolistic SOEs were able to set monopolistic prices, earn monopolistic profits and pay their employees' wages that were higher than their marginal product. These might be the chief reasons that the wages in SOEs increased faster than did those in the public sector and private sector.

More than 30 years has passed since China's economic reforms were initiated in 1978. During these decades, the most spectacular and influential reforms were the abolishment of the collective agricultural regime in the early 1980s and the radical SOE reform in the late 1990s, which involved the retrenchment of half of all SOE employees and the privatization of the 
majority of SOEs. The rural reform, which returned collectivized land to rural households, resulted in a large rise in agricultural output and a significant fall in rural poverty. It can be regarded as a pure Pareto improvement- there were no losers during the reform. However, the radical SOE reform led to the retrenchment of half of the SOE workforce and a massive reduction in the number of SOEs. The SOE reforms eliminated the need for the majority of state fiscal income to be spent on subsidizing loss-making SOEs, and hence laid a solid financial foundation for the new Hu-Wen deal that focused on improving household living conditions. ${ }^{17}$

China's transitional market economy is still not perfect. The large monopolistic SOEs play a dominant role and pay their employees very high salaries and welfare payments, which has contributed to the rise in urban wage inequality. For this reason, decision makers should put more effort into monitoring and regulating monopolistic SOEs.

The results of the multiple quantile regressions suggest that pay in the public sector was higher than that in SOEs in both 1995 and 2002, but the gap decreased as the wage levels increase in each of the two years. In 2007 there were no significant pay differentials between the public sector and SOEs, except that the pay in the latter was higher than that in the former for the top quintile. This implies that after 2002 there were larger pay rises in SOEs than in the public sector.

Before the state sector reforms, SOE managers had few credit constraints, little business risk and incentive to raise pay for workers, and the aim of SOEs was not the maximization of profits and total wealth, but rather the maximization of the pay and welfare of workers. Therefore, the main determinant of wages in SOEs was the amount of retained profit, rather than the productivity of the workers. The consequence of this former regime was that the wage premium of the state sector versus non-state sector increased considerably in the period from 1988 to 1995, which caused an increase in urban wage inequality.

During the SOE reform, the wage premium of the state sector was reduced temporarily, leading to a fall in urban wage inequality for the period from 1995 to 2002. However, the SOEs that survived the reform are large and monopolistic, characterized by opportunistic monopolistic profit and payment of high salaries. Therefore, since 2002, the rate of pay rises for SOE workers has not only been faster than that of the public sector but has also been faster than that of the private sector, which led to an increase in urban wage inequality. The Oaxaca-Blinder decomposition showed that the unreasonable part of the wage premium of the state sector versus non-state sector remained at about $44 \%$ until 2002, but then increased sharply to $81 \%$ in 2007. The monopolistic SOEs were able to set monopolistic prices, earn monopolistic profits and pay their employees' wages that were higher than their marginal product. These might be the chief reasons that the wages in SOEs increased faster than did those in the public sector and private sector.

We also extended the MM counterfactual decompositions to all decile points in order to investigate the effect of change in the state sector's employment share on urban wage inequality. The state sector consists of the public sector and SOEs. The SOEs' share of total urban employment fell from 50\% in 1995 to $18 \%$ in 2007, while the public sector's share remained at about $30 \%$. The results of the multiple quantile regressions and MM counterfactual decomposition revealed that after the radical SOE reform, the fall of employment share of SOE

\footnotetext{
${ }^{17} \mathrm{The} \mathrm{Hu}-$ Wen new deal is referred to as Hu Jingtao and Wen Jiabao's policy because it came into effect since 2002.
} 
sector resulted in a decrease of urban wage inequality, but the wage premium of SOE workers and its unreasonable part increased significantly, which in turn led to an increase in urban wage inequality.

More than 30 years has passed since China's economic reforms were initiated in 1978. During these decades, the most spectacular and influential reforms were the abolishment of the collective agricultural regime in the early 1980s and the radical SOE reform in the late 1990s, which involved the retrenchment of half of all SOE employees and the privatization of the majority of SOEs. The rural reform, which returned collectivized land to rural households, resulted in a large rise in agricultural output and a significant fall in rural poverty. Therefore, it was a pure Pareto improvement - there were no losers during the reform. However, the radical SOE reform led to the retrenchment of half of the SOE workforce and a massive reduction in the number of SOEs. The SOE reforms eliminated the need for the majority of state fiscal income to be spent on subsidizing loss-making SOEs, and hence laid a solid financial foundation for the new $\mathrm{Hu}-$ Wen deal that focused on improving household living conditions. ${ }^{18}$

China's transitional market economy is still not perfect. The large monopolistic SOEs play a dominant role and pay their employees very high salaries and welfare payments without much of justification, which have led to the rise in urban wage inequality. For this reason, decision makers should put more effort into monitoring and regulating monopolistic SOEs.

\footnotetext{
${ }^{18}$ The Hu-Wen new deal is referred to as Hu Jingtao and Wen Jiabao’s policy because it came into effect since 2002.
} 


\section{References}

Albrecht, J., A. Björklund, S. Vroman (2003). Is There a Glass Ceiling in Sweden? Journal of Labor Economics, 21(1): 145-177.

Angrist, J. D., J. Pischke (2009). Mostly Harmless Econometrics: An Empiricist's Companion. Princeton: Princeton University Press.

Appleton, S., J. Knight, L. Song and Q. Xia (2004). Contrasting paradigms: Segmentation and competitiveness in the Formation of the Chinese Labour Market. Journal of Chinese Economics and Business Studies, 2(3): 195-205.

Appleton, S., L. Song and Q. Xia (2005). Has China Crossed the River? The Evolution of Wage Structure in Urban China during Reform and Retrenchment. Journal of Comparative Economics, 33(4): 644-663.

Bai, C., J. Lu, Z. Tao (2006). An Empirical Study of Effect of Restructure of State-Owned Enterprises. Economic Research Journal, No. 8 of 2006, 4-13. (guo you qi ye gai zhi xiao guo de shi zheng yan jiu, jing ji yan jiu, 2006 nian di 8 qi, di 4-13 ye).

Bai, Y. (2008). On Equity of Earning Distribution intra State-Owned Enterprises: A Case Study of M Firm. Nankai Review of Management, 11 (4): 63-69. (guo you qi ye nei bu shou ru gong ping xing yan jiu - ji yu M gong si de an li yan jiu, nan kai guan li ping lun, 2008 nian di 11 juan, di 4 qi, di 63-69 ye).

Blinder, A. S. (1973). Wage Discrimination: Reduced Form and Structural Estimates. The Journal of Human Resources 8: $436 \square 455$.

Buchinsky, M. (1994). Changes in the U.S. Wage Structure 1963-1987: Application of Quantile Regression. Econometrica, 62: 405-458.

Cai, F., A. Park, Y. Zhao (2008) The Chinese Labor Market in the Reform Era, in Loren Brandt and Thomas Rawski (eds.) China's Great Economic Transformation, Cambridge University Press.

Chamberlin, G. (1994), Quantile regression, censoring, and the structure of wages. In: Sims, C. (eds.), Advances in Econometrics: Sixth World Congress, Chapter 5, pages 171-208. New York: CUP.

Dai, B. H., Q. G. Lou, X. X. Wang (2005). On Civil Servants’ Wage Income. The Web of Ministry of Finance, PRC. (guan yu gong wu yuan shou ru fen pei wen ti yan jiu, cai zheng bu wang zhan).

http://www.mof.gov.cn/pub/caizhengbuzhuzhan/zhengwuxinxi/diaochayanjiu/200806/t20 080619_47096.html.

Dai, Yuanchen (1994). Cultivation of Chinese Labor Market and Wage Reform. Beijing: Chinese Labor Press (Zhongguo lao dong li shi chang pei yu yu gong zi gai ge. Beijing: Zhongguo lao dong chu ban she).

Deaton, A. (1997). The Analysis of Household Surveys. The John Hopkins University Press. 
Fleischer, B. M., D. Yang (2004). China's Labor Market. Paper presented at the Conference on China's Market Reform, Stanford Center for International Development, Stanford University, September 19-20, 2003.

Griffin, K., R. Zhao (Eds.) (1993). The Distribution of Income in China. Macmillan and Co., London.

Gu, Y., Y. Feng(2008). Is the income distribution between industries polarised? Evidence from a NonParametric kernel density estimation (wo guo hang ye shou ru fen pei liang ji fen hua le ma? Lai zi fei chan shu kernel mi du gu ji de zheng ju). Economic Review (jing ji ping lun), Issue 4 of 2008, page 5-13

Hao, L., D. Naiman (2007), Quantile Regression. The SAGE Publications, Inc.

Huang, Yasheng (2008). Capitalism with Chinese Characteristics. New York, CUP.

Jia, Kang(2011). Seven Causes of Income Gap. Exploration of Decision-Making, Issue 3 of 2011, 6-7. (pin fu cha ju qi zhong cheng yin, jue ce tan suo).

Gustafsson, B. A., S. Li, T. Sicular (2008). Inequality and Public Policy in China. Newyork: CUP.

Knight, J., L. Song (1993) Why urban wages differ in China, in: K. Griffin and R. Zhao (Eds), The Distribution of Income in China, pp. 216-284, London: Macmillan.

Knight, J., L. Song (2003). Increasing urban wage inequality in China, Economics of Transition, 11(4): 597-619.

Kocherginsky, M., X. He, Y. Mu (2005). Practical Confidence Intervals for Regression Quantiles. Journal of Computational and Graphical Statistics. 14(1): 41-55.

Koenker, R. (2005). Quantile Regression. New York: CUP.

Koenker, R. and G. Bassett (1978). Regression Quantiles. Econometrica, 46(1): 33-50.

Koenker, R. and G. Bassett (1982). Robust Tests for Heteroscedasticity Based on Regression Quantiles. Econometrica, 50: 43-61.

Koenker, R., K. F. Hallock (2001). Quantile Regression. Journal of Economic Perspective, 15(4): 143-156.

Lardy, N. R. (1998), China's Unfinished Economic Revolution. Washington, DC: Brookings Institution.

Li, S., H. Sato (ed.) (2006). Unemployment, Inequality and Poverty in Urban China, London and New York: Routledge Curzon.

Liao, J., L. Zhang, Z. Liu (2006). On Gini Coefficient and Reasonableness of Pay Distribution Intra-Firm. China Industrial Economy, No. 2 of 2006, 98-106. (ji ni xi shu yu 
qi ye nei bu xin chou fen pei he li xin yan jiu, zhong guo gong ye jing ji, 2006 nian di 2 qi, zong di 215 qi, di 98-106 ye)

Liu, Xin (2006). Understanding of Reform of Civil Servants' Wage: It isn’t just Pay Rise. Digest for Party Workers and Civil Servants, Issue 8 of 2006. (jie du gong wu yuan gong zi gai ge bing fei zhi shi dan chun zhang gong zi, dang zheng gan bu wen zhai).

Luo, Chuliang (2007). Return to Urban Residents' Education and its Distributional Characteristics. Economic Research Journal, Issue 6 of 2007, 119-130. (cheng zhen ju min jiao yu shou yi lu ji qi fen bu te zheng, jing ji yan jiu).

Machado, J. A. F., J. Mata (2005). Counterfactual Decomposition of Changes in Wage Distributions Using Quantile Regression. Journal of Applied Econometrics, 20(3): 445-465.

Meng, X. (2000). Labour Market Reform in China. London: Cambridge University Press.

Mincer, J. (1974/1993). Schooling, Experience and Earnings. New York: Columbia University Press, and then New York: Gregg Revivals.

Ministry of Human Resources and Social Security (2010). Statistical Report of Development of Human Resources and Social Security of 2009, China News Net, (2009 nian ren li zi yuan he she hui bao zhang fa zhan tong ji gong bao fa bu, zhong guo xin wen wang), http://www.chinanews.com.cn/cj/news/2010/05-21/2298093.shtml.

National Commission of Development and Reform (NCDR) (2007), The Annual Report of Residential Income Distribution (2006) (zhong guo ju min shou ru fen pei nian du bao gao (2006)).

Naughton, B. (2007). The Chinese Economy. Cambridge: MIT Press.

News Office of State Council (2004). The White Paper on the Situation and Policies of Employment of China (zhong guo de jiu ye zhang kuang he zheng ce bai pi shu), Beijing: April of 2004.

NSB (1993), The Statistic Year Book 1992, Beijing: the Statistical Press of China.

NSB (2002), The Statistic Year Book 2001, Beijing: the Statistical Press of China.

NSB (2008), The Statistic Year Book 2001, Beijing: the Statistical Press of China.

Oaxaca R. (1973). Male-female differentials in urban labor markets. International Economic Review, 14: 693-709.

OECD (2004). Trends and Recent Developments in Foreign Direct Investment. June 2004. Qu, Zhaopeng, Zhong Zhao (2008). Urban-Rural Consumption Inequality in China from 1988 to 2002: Evidence from Quantile Regression Decomposition. IZA Discussion Paper, No. 3659.

Rica, S., Dolado J., Llorens, V. (2008). Ceilings or floors? Gender wage gaps by education 
in Spain. Journal of Population Economics, 21: 751-776.

Riskin, C., R. Zhao, S. Li (2001). China's Retreat from Equality: Income Distribution and Economic Transition. M.E. Sharpe, Armonk, New York.

Walder, A. (1987). Wage Reform and the Web of Factory Interests. The China Quarterly, 109: 22-41.

Walder, A. (1989). Factory and Manager in an Era of Reform. The China Quarterly, 118: 242-64.

Wen, Jiabao (2010). Report on the Work of The Government. Beijing, $5^{\text {th }}$ March 2010. (zheng fu gong zuo bao gao).

Wu, Jinglian (2006). The Speech at Changan Forum of "the Forum of 50 People on the Chinese Economy" (zai "zhong guo jing ji 50 ren lun tan" chang an jiang tan shang de jiang hua), Beijing, June 25 of 2006.

Xia, Q., L. Song, S. Appleton (2009). The Change of Wage Payment Structure of Urban China during Economic Transition, China Population Science, Issue 6 of 2009, 59-68. (jing ji zhuan xing qi jian zheng zhen gong zi zhi fu jie gou de bian qian, zhong guo ren kou ke xue).

Yue, X., S. Li, T. Sicular (2010). On Issue of High Pay of Monopolistic Industries. Social Science of China, Issue 3 of 2010, 77-93. (long duan hang ye gao shou ru wen ti tan suo, zhong guo she hui ke xue).

Liwei Zhang (2012), “Economic Balance and Direction of China” Financial Times Chinese Version $14^{\text {th }}$ December 2012, http://www.ftchinese.com/story/001048020

Zhang, J. S., Y. Zhao, A. Park, X. Song (2005). Economic returns to schooling in urban China, 1988-2001. Journal of Comparative Economics 33 (4): 730-752.

Zhu, Rongji (2011). Recording Version of Zhu Rongji’s Speeches, Beijing: People Press. (Zhu Rong Ji Jiang Hua Shi Lu, ren min chu ban she, 2011 nian 9 yue di 1 ban). 
Table 1: Indicators of wage inequality of urban China

\begin{tabular}{|l|c|c|c|c|}
\hline & 1988 & 1995 & 2002 & 2007 \\
\hline Gini coefficients & 0.23720 & 0.34449 & 0.34781 & 0.43937 \\
\hline General entropy & & & & \\
\hline GE(-1) & 0.23790 & 0.57580 & 0.28577 & 0.40476 \\
\hline GE(0) & 0.10786 & 0.23536 & 0.21241 & 0.33339 \\
\hline GE(1) & 0.10766 & 0.22646 & 0.21514 & 0.44610 \\
\hline GE(2) & 0.14837 & 0.37869 & 0.29688 & 1.97441 \\
\hline Atkinson index & \multicolumn{5}{|l|}{} \\
\hline A(0.5) & 0.05124 & 0.10560 & 0.10053 & 0.16938 \\
\hline A(1) & 0.10224 & 0.20971 & 0.19137 & 0.28351 \\
\hline A(2) & 0.32240 & 0.53523 & 0.36368 & 0.44737 \\
\hline Mean & 17.60 & 28.20 & 49.73 & 98.54 \\
\hline Median & 16.53 & 23.99 & 41.83 & 69.24 \\
\hline Standard deviation & 9.41 & 24.61 & 38.32 & 198.31 \\
\hline Ratios of wages of percentile points & 2.82 & 5.04 & 4.96 & 6.43 \\
\hline p90/p10 & 1.65 & 2.17 & 2.29 & 2.80 \\
\hline p75/p25 & 1.57 & 1.99 & 2.08 & 2.57 \\
\hline p90/p50 & 1.80 & 2.54 & 2.38 & 2.50 \\
\hline P50/p10 & 7.16 & 11.09 & 4.32 & 32.64 \\
\hline Skewness & \multicolumn{5}{|l}{} \\
\hline
\end{tabular}

Source: CHIP 1988, 1995, 2002 and 2007 urban household survey.

When only relative values are involved, wages are in nominal price; whereas when absolute values are needed, wages of other years are all adjusted to the 2002 constant prices according to the urban consumer price index of China Statistical Yearbooks of various years. 
Table 2: Indicators of wage inequality and gap of urban China by ownership sector

\begin{tabular}{|c|c|c|c|c|c|c|c|c|}
\hline & \multicolumn{2}{|c|}{1988} & \multicolumn{2}{|c|}{1995} & \multicolumn{2}{|c|}{2002} & \multicolumn{2}{|c|}{2007} \\
\hline & state & Non-state & state & Non-state & state & Non-state & state & Non-state \\
\hline $\begin{array}{l}\text { Gini } \\
\text { coefficients }\end{array}$ & 0.221 & 0.278 & 0.326 & 0.396 & 0.314 & 0.392 & 0.392 & 0.481 \\
\hline \multicolumn{9}{|c|}{ General entropy } \\
\hline GE(-1) & 0.135 & 0.515 & 0.452 & 0.870 & 0.228 & 0.343 & 0.321 & 0.471 \\
\hline GE(0) & 0.092 & 0.149 & 0.206 & 0.314 & 0.174 & 0.264 & 0.265 & 0.397 \\
\hline GE(1) & 0.095 & 0.144 & 0.206 & 0.295 & 0.174 & 0.290 & 0.326 & 0.577 \\
\hline GE(2) & 0.136 & 0.188 & 0.351 & 0.486 & 0.224 & 0.476 & 1.013 & 3.181 \\
\hline \multicolumn{9}{|c|}{ Atkinson index } \\
\hline $\mathrm{A}(0.5)$ & 0.045 & 0.069 & 0.095 & 0.137 & 0.083 & 0.128 & 0.133 & 0.205 \\
\hline $\mathrm{A}(1)$ & 0.088 & 0.139 & 0.186 & 0.270 & 0.160 & 0.232 & 0.233 & 0.328 \\
\hline$A(2)$ & 0.213 & 0.508 & 0.475 & 0.635 & 0.313 & 0.407 & 0.391 & 0.485 \\
\hline Mean & 18.36 & 14.98 & 29.828 & 22.05 & 53.83 & 42.19 & 104.55 & 92.57 \\
\hline Median & 17.35 & 13.68 & 25.44 & 17.95 & 47.66 & 31.82 & 79.99 & 59.59 \\
\hline $\begin{array}{l}\text { Standard } \\
\text { deviation }\end{array}$ & 9.45 & 8.78 & 25.088 & 21.65 & 36.01 & 41.19 & 151.41 & 235.70 \\
\hline \multicolumn{9}{|c|}{ Ratios of wages of percentile points } \\
\hline p90/p10 & 2.59 & 3.43 & 4.35 & 6.71 & 4.30 & 5.45 & 5.64 & 6.90 \\
\hline p75/p25 & 1.57 & 1.79 & 2.03 & 2.46 & 2.02 & 2.36 & 2.50 & 2.83 \\
\hline p90/p50 & 1.52 & 1.71 & 1.92 & 2.25 & 1.91 & 2.46 & 2.28 & 2.80 \\
\hline $\mathrm{P} 50 / \mathrm{p} 100$ & 1.70 & 2.01 & 2.26 & 2.99 & 2.25 & 2.22 & 2.47 & 2.46 \\
\hline Skewness & 8.20 & 3.79 & 11.90 & 7.63 & 3.59 & 5.60 & 26.886 & 31.719 \\
\hline
\end{tabular}

Source: CHIP 1988, 1995, 2002 and 2007 urban household survey.

When only relative values are involved, wages are in nominal price; whereas when absolute values are needed, wages of other years are all adjusted to the 2002 constant prices according to the urban consumer price index of China Statistical Yearbooks of various years. 
Table 3: Indicators of wage inequality and gap of urban China by subsectors

\begin{tabular}{|c|c|c|c|c|c|c|c|c|c|c|c|c|c|c|c|c|c|c|c|c|c|c|c|c|}
\hline & \multicolumn{6}{|c|}{1988} & \multicolumn{6}{|c|}{1995} & \multicolumn{6}{|c|}{2002} & \multicolumn{6}{|c|}{2007} \\
\hline & $\begin{array}{c}\text { Publ } \\
\text { ic } \\
\text { secto } \\
\text { r } \\
\end{array}$ & $\begin{array}{l}\text { SO } \\
\text { Es }\end{array}$ & $\begin{array}{l}\text { Collecti } \\
\text { ve } \\
\text { firms }\end{array}$ & $\begin{array}{l}\text { Priva } \\
\text { te } \\
\text { firms }\end{array}$ & $\begin{array}{c}\text { Forei } \\
\text { gn } \\
\text { firms }\end{array}$ & $\begin{array}{l}\text { Othe } \\
\text { rs }\end{array}$ & $\begin{array}{c}\text { Publ } \\
\text { ic } \\
\text { secto } \\
\mathrm{r} \\
\end{array}$ & $\begin{array}{l}\text { SO } \\
\text { Es }\end{array}$ & $\begin{array}{l}\text { Collecti } \\
\text { ve } \\
\text { firms }\end{array}$ & $\begin{array}{l}\begin{array}{l}\text { Priva } \\
\text { te } \\
\text { firms }\end{array}\end{array}$ & $\begin{array}{c}\begin{array}{c}\text { Forei } \\
\text { gn } \\
\text { firms }\end{array}\end{array}$ & $\begin{array}{l}\text { Othe } \\
\text { rs }\end{array}$ & $\begin{array}{c}\text { Publ } \\
\text { ic } \\
\text { secto } \\
\text { r } \\
\end{array}$ & $\begin{array}{l}\text { SO } \\
\text { Es }\end{array}$ & $\begin{array}{l}\text { Collecti } \\
\text { ve } \\
\text { firms }\end{array}$ & $\begin{array}{c}\text { Priva } \\
\text { te } \\
\text { firms }\end{array}$ & $\begin{array}{l}\text { Forei } \\
\text { gn } \\
\text { firms }\end{array}$ & $\begin{array}{l}\text { Othe } \\
\text { rs }\end{array}$ & $\begin{array}{c}\text { Publ } \\
\text { ic } \\
\text { secto } \\
\text { r } \\
\end{array}$ & $\begin{array}{c}\mathrm{SOE} \\
\mathrm{s}\end{array}$ & $\begin{array}{l}\text { Collecti } \\
\text { ve } \\
\text { firms }\end{array}$ & $\begin{array}{l}\text { Priva } \\
\text { te } \\
\text { firms }\end{array}$ & $\begin{array}{c}\text { Forei } \\
\text { gn } \\
\text { firms }\end{array}$ & $\begin{array}{l}\text { Othe } \\
\text { rs }\end{array}$ \\
\hline Mean & $\begin{array}{c}18.3 \\
6 \\
\end{array}$ & & 14.82 & $\begin{array}{c}18.0 \\
8 \\
\end{array}$ & 24.67 & $\begin{array}{c}12.0 \\
3 \\
\end{array}$ & $\begin{array}{c}32.8 \\
7 \\
\end{array}$ & $\begin{array}{c}28.0 \\
3 \\
\end{array}$ & 21.10 & $\begin{array}{c}18.0 \\
5 \\
\end{array}$ & 34.38 & $\begin{array}{c}19.5 \\
0 \\
\end{array}$ & $\begin{array}{c}59.2 \\
2 \\
\end{array}$ & $\begin{array}{c}48.9 \\
1 \\
\end{array}$ & 34.71 & $\begin{array}{c}42.5 \\
1 \\
\end{array}$ & 67.03 & $\begin{array}{c}40.4 \\
7 \\
\end{array}$ & $\begin{array}{c}106 . \\
48 \\
\end{array}$ & $\begin{array}{c}101 . \\
13 \\
\end{array}$ & 89.97 & $\begin{array}{c}88.8 \\
9 \\
\end{array}$ & $\begin{array}{c}125.1 \\
3 \\
\end{array}$ & $\begin{array}{c}65.0 \\
6 \\
\end{array}$ \\
\hline Median & $\begin{array}{c}17.3 \\
5 \\
\end{array}$ & & 13.77 & $\begin{array}{c}11.5 \\
9 \\
\end{array}$ & 22.98 & $\begin{array}{c}10.5 \\
5 \\
\end{array}$ & $\begin{array}{c}28.1 \\
9 \\
\end{array}$ & $\begin{array}{c}23.5 \\
3 \\
\end{array}$ & 17.63 & $\begin{array}{c}12.8 \\
2 \\
\end{array}$ & 28.23 & $\begin{array}{c}16.6 \\
6 \\
\end{array}$ & $\begin{array}{c}53.2 \\
3 \\
\end{array}$ & $\begin{array}{c}41.1 \\
2 \\
\end{array}$ & 28.00 & $\begin{array}{c}31.8 \\
7 \\
\end{array}$ & 54.97 & $\begin{array}{c}30.0 \\
3 \\
\end{array}$ & $\begin{array}{c}82.8 \\
5 \\
\end{array}$ & $\begin{array}{c}71.9 \\
9 \\
\end{array}$ & 58.49 & $\begin{array}{c}55.8 \\
7 \\
\end{array}$ & 86.30 & $\begin{array}{c}46.1 \\
4 \\
\end{array}$ \\
\hline $\begin{array}{c}\text { Standar } \\
\mathrm{d} \\
\text { deviati } \\
\text { on } \\
\end{array}$ & 9.45 & & 7.78 & $\begin{array}{c}19.2 \\
2\end{array}$ & 15.75 & 8.90 & $\begin{array}{c}23.7 \\
5\end{array}$ & $\begin{array}{c}25.8 \\
6\end{array}$ & 20.20 & $\begin{array}{c}17.5 \\
0\end{array}$ & 28.75 & $\begin{array}{c}17.6 \\
9\end{array}$ & $\begin{array}{c}34.6 \\
4\end{array}$ & $\begin{array}{c}36.5 \\
3\end{array}$ & 24.63 & $\begin{array}{c}42.7 \\
3\end{array}$ & 50.46 & $\begin{array}{c}43.8 \\
6\end{array}$ & $\begin{array}{c}101 . \\
19\end{array}$ & $\begin{array}{c}212 . \\
97\end{array}$ & 266.03 & $\begin{array}{c}252 . \\
95\end{array}$ & $\begin{array}{c}157.7 \\
3\end{array}$ & $\begin{array}{c}72.3 \\
6\end{array}$ \\
\hline $\begin{array}{l}\text { Gini } \\
\text { index }\end{array}$ & $\begin{array}{c}0.22 \\
1\end{array}$ & & 0.255 & $\begin{array}{c}0.47 \\
4\end{array}$ & 0.369 & $\begin{array}{c}0.40 \\
2\end{array}$ & $\begin{array}{c}0.30 \\
2\end{array}$ & $\begin{array}{c}0.33 \\
8\end{array}$ & 0.372 & $\begin{array}{c}0.45 \\
2\end{array}$ & 0.362 & $\begin{array}{c}0.44 \\
8\end{array}$ & $\begin{array}{c}0.28 \\
7\end{array}$ & $\begin{array}{c}0.33 \\
1\end{array}$ & 0.336 & $\begin{array}{c}0.38 \\
6\end{array}$ & 0.351 & $\begin{array}{c}0.39 \\
9\end{array}$ & $\begin{array}{c}0.37 \\
9\end{array}$ & $\begin{array}{c}0.41 \\
4\end{array}$ & 0.463 & $\begin{array}{c}0.48 \\
9\end{array}$ & 0.436 & $\begin{array}{c}0.40 \\
5\end{array}$ \\
\hline Ratios o & wages & varig & s percent & points & & & & & & & & & & & & & & & & & & & & \\
\hline $\begin{array}{c}\mathrm{p} 90 / \mathrm{p} 1 \\
0\end{array}$ & 2.59 & & 3.09 & $\begin{array}{c}11.8 \\
9\end{array}$ & 7.79 & $\begin{array}{c}13.7 \\
8\end{array}$ & 3.61 & 4.73 & 5.68 & 9.34 & 5.40 & $\begin{array}{c}19.9 \\
5\end{array}$ & 3.79 & 4.37 & 4.37 & 5.36 & 5.03 & 5.36 & 5.88 & 5.00 & 5.25 & 7.00 & 7.00 & 6.00 \\
\hline $\begin{array}{c}\mathrm{p} 75 / \mathrm{p} 2 \\
5\end{array}$ & 1.57 & & 1.73 & 3.17 & 2.65 & 2.91 & 1.81 & 2.15 & 2.25 & 2.88 & 2.21 & 4.22 & 1.83 & 2.14 & 2.17 & 2.30 & 2.52 & 2.50 & 2.46 & 2.45 & 2.39 & 2.67 & 2.80 & 2.25 \\
\hline $\begin{array}{c}\mathrm{p} 90 / \mathrm{p} 5 \\
0\end{array}$ & 1.52 & & 1.64 & 3.23 & 2.19 & 2.39 & 1.89 & 2.00 & 2.17 & 2.94 & 2.12 & 2.39 & 1.80 & 2.03 & 2.23 & 2.41 & 2.22 & 2.39 & 2.40 & 2.29 & 2.50 & 3.00 & 2.92 & 2.68 \\
\hline $\begin{array}{c}\mathrm{P} 50 / \mathrm{p} 1 \\
0\end{array}$ & 1.70 & & 1.89 & 3.68 & 3.56 & 5.75 & 1.92 & 2.36 & 2.62 & 3.17 & 2.54 & 8.33 & 2.10 & 2.15 & 1.96 & 2.22 & 2.27 & 2.24 & 2.45 & 2.19 & 2.10 & 2.33 & 2.40 & 2.24 \\
\hline $\begin{array}{c}\text { Skewn } \\
\text { ess }\end{array}$ & 8.20 & & 3.46 & 3.41 & 0.68 & 1.03 & 5.90 & $\begin{array}{c}14.6 \\
1\end{array}$ & 9.26 & 2.54 & 3.65 & 2.57 & 2.47 & 4.69 & 2.68 & 5.69 & 3.75 & 6.41 & 6.99 & $\begin{array}{c}25.4 \\
7\end{array}$ & 17.83 & $\begin{array}{c}33.7 \\
0\end{array}$ & 9.05 & 5.54 \\
\hline
\end{tabular}

Source: CHIP 1988, 1995, 2002 and 2007 urban household survey.

When only relative values are involved, wages are in nominal price; whereas when absolute values are needed, wages of other years are all adjusted to the 2002 constant prices according to the urban consumer price index of China Statistical Yearbooks of various years. 
Table 4: Ownership structure of the employed urban workers

\begin{tabular}{|l|c|c|c|c|}
\hline & 1988 & 1995 & 2002 & 2007 \\
\hline No. of observations & 17,733 & 12,245 & 10,133 & 6,938 \\
\hline Ownership structure of the employed urban workers (\%) \\
\hline State sector & 77.67 & 79.04 & 64.76 & 49.83 \\
\hline Public service sector & & 29.66 & 30.90 & 31.82 \\
\hline SOEs & & 50.95 & 33.86 & 18.00 \\
\hline Urban collective firms & 20.28 & 15.06 & 6.86 & 5.36 \\
\hline Private firms & 0.77 & 1.65 & 20.72 & 34.48 \\
\hline Foreign-owned and joint-venture firms & 0.36 & 1.27 & 2.17 & 7.08 \\
\hline Other ownerships & 0.92 & 2.98 & 5.49 & 3.26 \\
\hline
\end{tabular}

Source: CHIP 1988, 1995, 2002 and 2007 urban household surveys. 
Table 5: Oaxaca-Blinder Decomposition of pay differential between the state and non-state sectors

\begin{tabular}{|c|c|c|c|c|}
\hline & 1988 & 1995 & 2002 & 2007 \\
\hline Amount attributable: & 1.0 & 5.6 & 33.9 & 24.8 \\
\hline - due to endowments (E): & 14.5 & 23.1 & 18.5 & 4.9 \\
\hline - due to coefficients (C): & -13.4 & -17.5 & 15.4 & 19.9 \\
\hline Shift coefficient (U): & 24.5 & 34.9 & -0.6 & 0.6 \\
\hline Raw differential (R) $\{\mathrm{E}+\mathrm{C}+\mathrm{U}\}:$ & 25.5 & 40.5 & 33.3 & 25.4 \\
\hline Adjusted differential (D) $\{\mathrm{C}+\mathrm{U}\}:$ & 11.1 & 17.4 & 14.8 & 20.6 \\
\hline Endowments as \% total (E/R): & 56.7 & 57.0 & 55.6 & 19.2 \\
\hline Discrimination as \% total (D/R): & 43.3 & 43.0 & 44.4 & 80.8 \\
\hline
\end{tabular}

Source: CHIP 1988, 1995, 2002 and 2007 urban household survey.

Wages of other years are all adjusted to the 2002 constant prices according to the urban consumer price index of China Statistical Yearbooks of various years.

$\mathrm{U}=$ unexplained portion of differential (difference between model constants).

$\mathrm{D}=$ portion due to discrimination $(\mathrm{C}+\mathrm{U})$. 
Table 6

MM counterfactual decomposition of the effect of wage structure and employment share of state sector versus non-state sector on urban wage inequality based on the beginning year's wage structure

\begin{tabular}{|c|c|c|c|c|c|c|}
\hline & \multicolumn{3}{|c|}{ Change of coefficients } & \multicolumn{3}{|c|}{ Change of covariates } \\
\hline & 1988-1995 & 1995-2002 & $2002-2007$ & 1988-1995 & $1995-2002$ & $2002-2007$ \\
\hline Gini & $\begin{array}{c}0.007 \\
(.005, .009) \\
(+10)\end{array}$ & $\begin{array}{c}-0.012 \\
(-.014,-.007) \\
(+0)\end{array}$ & $\begin{array}{c}0.003 \\
(.003, .004) \\
(+10)\end{array}$ & $\begin{array}{c}-0.001 \\
(-.005, .002) \\
(+1)\end{array}$ & $\begin{array}{c}-0.001 \\
(-.006, .002) \\
(+5)\end{array}$ & $\begin{array}{c}0.000 \\
(-.003, .002) \\
(+7)\end{array}$ \\
\hline Mean & $\begin{array}{c}1.44 \\
(1.36,1.52) \\
(+10)\end{array}$ & $\begin{array}{c}-2.60 \\
(-2.75,-2.48) \\
(+0)\end{array}$ & $\begin{array}{c}0.96 \\
(0.92,1.02) \\
(+10) \\
\end{array}$ & $\begin{array}{c}-0.01 \\
(-0.05,0.02) \\
(+4) \\
\end{array}$ & $\begin{array}{c}-0.95 \\
(-1.16,-0.79) \\
(+0)\end{array}$ & $\begin{array}{c}-0.95 \\
(-1.13,-0.79) \\
(+0) \\
\end{array}$ \\
\hline Median & $\begin{array}{c}1.30 \\
(1.07,1.48) \\
(+10)\end{array}$ & $\begin{array}{c}-1.78 \\
(-2.10,-1.47) \\
(+0)\end{array}$ & $\begin{array}{c}0.55 \\
(0.10,0.95) \\
(+10)\end{array}$ & $\begin{array}{c}0.00 \\
(-0.20,0.10) \\
(+6)\end{array}$ & $\begin{array}{c}-0.85 \\
(-1.08,-0.47) \\
(+0)\end{array}$ & $\begin{array}{c}-1.14 \\
(-1.87,-0.44) \\
(+0)\end{array}$ \\
\hline $\begin{array}{l}\text { Standard } \\
\text { deviation }\end{array}$ & $\begin{array}{c}1.18 \\
(0.69,2.60) \\
(+10)\end{array}$ & $\begin{array}{c}-4.07 \\
(-8.11,-2.14) \\
(+0)\end{array}$ & $\begin{array}{c}0.53 \\
(-0.48,1.10) \\
(+8)\end{array}$ & $\begin{array}{c}-0.04 \\
(-0.18,0.05) \\
(+3)\end{array}$ & $\begin{array}{c}-0.97 \\
(-2.43,-0.23) \\
(+0)\end{array}$ & $\begin{array}{c}-0.29 \\
(-1.61,0.41) \\
(+3)\end{array}$ \\
\hline Skewness & $\begin{array}{c}0.74 \\
(-0.54,4.43) \\
(+7)\end{array}$ & $\begin{array}{c}-1.94 \\
(-7.34,0.30) \\
(+1)\end{array}$ & $\begin{array}{c}-0.32 \\
(-1.06,0.12) \\
(+2)\end{array}$ & $\begin{array}{c}0.03 \\
(-0.15,0.30) \\
(+6)\end{array}$ & $\begin{array}{c}-0.33 \\
(-1.88,0.43) \\
(+4)\end{array}$ & $\begin{array}{c}0.20 \\
(-0.68,0.71) \\
(+9)\end{array}$ \\
\hline P90/P10 & $\begin{array}{c}0.13 \\
(0.06,0.18) \\
(+10)\end{array}$ & $\begin{array}{c}-0.11 \\
(-0.34,0.09) \\
(+1)\end{array}$ & $\begin{array}{c}0.11 \\
(0.04,0.18) \\
(+10)\end{array}$ & $\begin{array}{c}-0.02 \\
(-0.06,0.02) \\
(+3)\end{array}$ & $\begin{array}{c}-0.09 \\
(-0.31,0.09) \\
(+1)\end{array}$ & $\begin{array}{c}-0.09 \\
(-0.21,0.22) \\
(+1)\end{array}$ \\
\hline P75/P25 & $\begin{array}{c}0.04 \\
(0.01,0.05) \\
(+10)\end{array}$ & $\begin{array}{c}-0.06 \\
(-0.08,0.00) \\
(+0)\end{array}$ & $\begin{array}{c}0.05 \\
(0.02,0.09) \\
(+10)\end{array}$ & $\begin{array}{c}-0.01 \\
(-0.04,0.01) \\
(+1)\end{array}$ & $\begin{array}{c}0.01 \\
(-0.06,0.07) \\
(+5)\end{array}$ & $\begin{array}{c}-0.03 \\
(-0.09,0.02) \\
(+3)\end{array}$ \\
\hline P90/P50 & $\begin{array}{c}0.02 \\
(-0.01,0.05) \\
(+9)\end{array}$ & $\begin{array}{c}-0.05 \\
(-0.08,0.01) \\
(+1)\end{array}$ & $\begin{array}{c}0.04 \\
(0.00,0.06) \\
(+10)\end{array}$ & $\begin{array}{c}-0.01 \\
(-0.03,0.00) \\
(+1)\end{array}$ & $\begin{array}{c}-0.01 \\
(-0.06,0.03) \\
(+4)\end{array}$ & $\begin{array}{c}0.02 \\
(-0.04,0.05) \\
(+8)\end{array}$ \\
\hline P50/P10 & $\begin{array}{c}0.06 \\
(0.01,0.09) \\
(+10)\end{array}$ & $\begin{array}{c}0.01 \\
(-0.09,0.13) \\
(+6)\end{array}$ & $\begin{array}{c}0.01 \\
(-0.04,0.04) \\
(+6)\end{array}$ & $\begin{array}{c}0.00 \\
(-0.03,0.03) \\
(+5)\end{array}$ & $\begin{array}{c}-0.04 \\
(-0.15,0.04) \\
(+3)\end{array}$ & $\begin{array}{c}-0.06 \\
(-0.13,0.08) \\
(+1)\end{array}$ \\
\hline
\end{tabular}

Source: CHIP 1988, 1995, 2002 and 2007 urban household surveys.

Note: The decompositions are based on the beginning year's wage structure and explanatory variables for the periods from 1988 to 1995, 1995 to 2002, and 2002 to 2007. 
Table 7:

MM counterfactual decomposition of the effect of wage structure and employment share of state sector versus non-state sector on urban wage inequality based on the closing year's wage structure

\begin{tabular}{|c|c|c|c|c|c|c|}
\hline & \multicolumn{3}{|c|}{ Change of coefficients } & \multicolumn{3}{|c|}{ Change of covariates } \\
\hline & 1988-1995 & 1995-2002 & $2002-2007$ & 1988-1995 & $1995-2002$ & $2002-2007$ \\
\hline Gini & $\begin{array}{c}0.003 \\
(0.001,0.005) \\
(+10) \\
\end{array}$ & $\begin{array}{c}-0.014 \\
(-0.015,-0.009) \\
(+0) \\
\end{array}$ & $\begin{array}{c}0.002 \\
(0.001,0.003) \\
(+10) \\
\end{array}$ & $\begin{array}{c}-0.001 \\
(-0.003,0.002) \\
(+4) \\
\end{array}$ & $\begin{array}{c}0.007 \\
(0.005,0.01) \\
(+10) \\
\end{array}$ & $\begin{array}{c}0.008 \\
(-0.001,0.023) \\
(+9) \\
\end{array}$ \\
\hline Mean & $\begin{array}{c}2.14 \\
(2.07,2.28) \\
(+10)\end{array}$ & $\begin{array}{c}-4.55 \\
(-4.96,-4.14) \\
(+0)\end{array}$ & $\begin{array}{c}1.37 \\
(1.22,1.51) \\
(+10)\end{array}$ & $\begin{array}{c}-0.15 \\
(-0.26,-0.05) \\
(+0)\end{array}$ & $\begin{array}{c}-0.55 \\
(-0.73,-0.31) \\
(+0)\end{array}$ & $\begin{array}{c}-0.85 \\
(-2.05,1.85) \\
(+2)\end{array}$ \\
\hline Median & $\begin{array}{c}1.84 \\
(1.59,2.09) \\
(+10)\end{array}$ & $\begin{array}{c}-2.88 \\
(-3.38,-2.07) \\
(+0)\end{array}$ & $\begin{array}{c}0.73 \\
(-0.25,1.80) \\
(+9)\end{array}$ & $\begin{array}{c}-0.24 \\
(-0.86,0.09) \\
(+2)\end{array}$ & $\begin{array}{c}-0.77 \\
(-1.50,-0.21) \\
(+0)\end{array}$ & $\begin{array}{c}-1.19 \\
(-2.31,-0.06) \\
(+0)\end{array}$ \\
\hline $\begin{array}{l}\text { Standard } \\
\text { deviation }\end{array}$ & $\begin{array}{c}2.13 \\
(1.27,3.54) \\
(+10) \\
\end{array}$ & $\begin{array}{c}-8.48 \\
(-18.70,-3.90) \\
(+0)\end{array}$ & $\begin{array}{c}0.54 \\
(-0.33,2.30) \\
(+8) \\
\end{array}$ & $\begin{array}{c}0.10 \\
(-0.23,0.68) \\
(+4) \\
\end{array}$ & $\begin{array}{c}0.54 \\
(-0.29,1.64) \\
(+7) \\
\end{array}$ & $\begin{array}{c}15.45 \\
(-12.36,109.29) \\
(+7) \\
\end{array}$ \\
\hline Skewness & $\begin{array}{c}0.44 \\
(-0.15,2.79) \\
(+8) \\
\end{array}$ & $\begin{array}{c}-1.23 \\
(-4.59,0.41) \\
(+3)\end{array}$ & $\begin{array}{c}-0.16 \\
(-0.45,0.35) \\
(+2) \\
\end{array}$ & $\begin{array}{c}0.10 \\
(-0.29,0.28) \\
(+9) \\
\end{array}$ & $\begin{array}{c}0.08 \\
(-0.31,0.75) \\
(+4) \\
\end{array}$ & $\begin{array}{c}0.52 \\
(-1.86,3.99) \\
(+5) \\
\end{array}$ \\
\hline P90/P10 & $\begin{array}{c}0.14 \\
(-0.02,0.29) \\
(+9) \\
\end{array}$ & $\begin{array}{c}-0.26 \\
(-0.36,-0.13) \\
(+0) \\
\end{array}$ & $\begin{array}{c}0.13 \\
(-0.07,0.25) \\
(+8) \\
\end{array}$ & $\begin{array}{c}0.08 \\
(-0.20,0.23) \\
(+7) \\
\end{array}$ & $\begin{array}{c}0.27 \\
(0.110 .48) \\
(+10)\end{array}$ & $\begin{array}{c}0.11 \\
(-0.21,0.36) \\
(+7)\end{array}$ \\
\hline P75/P25 & $\begin{array}{c}0.05 \\
(0.00,0.08) \\
(+10)\end{array}$ & $\begin{array}{c}-0.06 \\
(-0.10,-0.02) \\
(+0)\end{array}$ & $\begin{array}{c}0.05 \\
(0.01,0.08) \\
(+10) \\
\end{array}$ & $\begin{array}{c}0.02 \\
(-0.04,0.07) \\
(+8)\end{array}$ & $\begin{array}{c}0.08 \\
(0.04,0.17) \\
(+10)\end{array}$ & $\begin{array}{c}0.03 \\
(-0.02,0.08) \\
(+8)\end{array}$ \\
\hline P90/P50 & $\begin{array}{c}0.00 \\
(-0.04,0.03) \\
(+8) \\
\end{array}$ & $\begin{array}{c}-0.07 \\
(-0.13,-0.02) \\
(+0)\end{array}$ & $\begin{array}{c}0.03 \\
(-0.02,0.09) \\
(+7) \\
\end{array}$ & $\begin{array}{c}0.00 \\
(-0.05,0.06) \\
(+6)\end{array}$ & $\begin{array}{c}0.04 \\
(0.00,0.08) \\
(+10) \\
\end{array}$ & $\begin{array}{c}0.01 \\
(-0.06,0.07) \\
(+5) \\
\end{array}$ \\
\hline P50/P10 & $\begin{array}{c}0.06 \\
(-0.01,0.11) \\
(+9)\end{array}$ & $\begin{array}{c}-0.04 \\
(-0.10,0.01) \\
(+0)\end{array}$ & $\begin{array}{c}0.02 \\
(-0.06,0.06) \\
(+8)\end{array}$ & $\begin{array}{c}0.04 \\
(-0.08,0.13) \\
(+8)\end{array}$ & $\begin{array}{c}0.08 \\
(0.03,0.17) \\
(+10)\end{array}$ & $\begin{array}{c}0.03 \\
(-0.06,0.11) \\
(+7)\end{array}$ \\
\hline
\end{tabular}

Source: CHIP 1988, 1995, 2002 and 2007 urban household survey.

The decompositions are based on the closing year's wage structure and explanatory variables for the periods from 1988 to 1995, 1995 to 2002, and 2002 to 2007. 
Table 8:

MM counterfactual decomposition of the effect of state sector' employment share on urban wage inequality

Table 8a: based on 1988's wage structure and other explanatory variables

\begin{tabular}{|c|c|c|c|c|c|}
\hline & Gini & $90^{\text {th }} / 10^{\text {th }}$ & $75^{\text {th }} / 25^{\text {th }}$ & $90^{\text {th }} / 50^{\text {th }}$ & $50^{\text {th }} / 10^{\text {th }}$ \\
\hline $77 \%$ to $10 \%$ & 0.008 & 0.11 & 0.03 & 0.05 & 0.01 \\
\hline $77 \%$ to $20 \%$ & 0.008 & 0.08 & 0.02 & 0.04 & 0.01 \\
\hline $77 \%$ to $30 \%$ & 0.006 & 0.06 & 0.02 & 0.02 & 0.01 \\
\hline $77 \%$ to $40 \%$ & 0.004 & 0.03 & 0.03 & 0.02 & 0.00 \\
\hline $77 \%$ to $50 \%$ & 0.003 & 0.02 & 0.01 & 0.01 & 0.00 \\
\hline $77 \%$ to $60 \%$ & 0.001 & 0.00 & -0.01 & 0.01 & -0.01 \\
\hline $77 \%$ to $65 \%$ & -0.001 & -0.04 & -0.01 & -0.01 & -0.02 \\
\hline $77 \%$ to $70 \%$ & 0.001 & 0.01 & -0.01 & 0.01 & 0.00 \\
\hline $77 \%$ to $75 \%$ & -0.001 & -0.03 & -0.01 & 0.00 & -0.01 \\
\hline $77 \%$ to $80 \%$ & -0.003 & -0.06 & -0.02 & -0.01 & -0.03 \\
\hline $77 \%$ to $85 \%$ & -0.003 & -0.05 & -0.02 & -0.01 & -0.02 \\
\hline $77 \%$ to $90 \%$ & -0.004 & -0.08 & -0.03 & -0.01 & -0.04 \\
\hline
\end{tabular}

Table 8b: based on 1995's wage structure and other explanatory variables

\begin{tabular}{|l|c|c|c|c|c|}
\hline & Gini & $90^{\text {th }} / 10^{\text {th }}$ & $75^{\text {th }} / 25^{\text {th }}$ & $90^{\text {th }} / 50^{\text {th }}$ & $50^{\text {th }} / 10^{\text {th }}$ \\
\hline $79 \%$ to $10 \%$ & 0.005 & 0.12 & 0.00 & 0.03 & 0.02 \\
\hline $79 \%$ to $20 \%$ & 0.009 & 0.10 & 0.03 & 0.04 & 0.00 \\
\hline $79 \%$ to $30 \%$ & 0.004 & 0.09 & 0.02 & 0.04 & 0.01 \\
\hline $79 \%$ to $40 \%$ & 0.006 & 0.04 & 0.00 & 0.01 & 0.00 \\
\hline $79 \%$ to $50 \%$ & 0.004 & 0.19 & 0.02 & 0.03 & 0.06 \\
\hline $79 \%$ to $60 \%$ & 0.004 & 0.09 & 0.03 & -0.01 & -0.04 \\
\hline $79 \%$ to $65 \%$ & -0.001 & -0.09 & 0.01 & 0.02 & -0.05 \\
\hline $79 \%$ to $70 \%$ & 0.001 & -0.05 & 0.01 & 0.00 & -0.06 \\
\hline $79 \%$ to $75 \%$ & -0.003 & -0.12 & 0.00 & -0.02 & -0.02 \\
\hline $79 \%$ to $85 \%$ & -0.006 & -0.09 & -0.03 & -0.01 & -0.07 \\
\hline $79 \%$ to $90 \%$ & -0.004 & -0.18 & -0.05 & & \\
\hline
\end{tabular}

Table 8c: based on 2002's wage structure and other explanatory variables

\begin{tabular}{|l|c|c|c|c|c|}
\hline & Gini & $90^{\text {th }} / 10^{\text {th }}$ & $75^{\text {th }} / 25^{\text {th }}$ & $90^{\text {th }} / 50^{\text {th }}$ & $50^{\text {th }} / 10^{\text {th }}$ \\
\hline $65 \%$ to $10 \%$ & 0.010 & 0.10 & 0.02 & 0.07 & -0.03 \\
\hline $65 \%$ to $20 \%$ & 0.008 & -0.02 & -0.02 & 0.06 & -0.07 \\
\hline $65 \%$ to $30 \%$ & 0.004 & -0.02 & -0.01 & 0.02 & -0.03 \\
\hline $65 \%$ to $40 \%$ & 0.004 & 0.02 & -0.02 & 0.06 & -0.05 \\
\hline $65 \%$ to $45 \%$ & 0.001 & -0.11 & -0.01 & 0.01 & -0.06 \\
\hline $65 \%$ to $50 \%$ & -0.002 & -0.11 & -0.02 & 0.02 & -0.07 \\
\hline $65 \%$ to $55 \%$ & -0.001 & -0.08 & -0.04 & 0.04 & -0.08 \\
\hline $65 \%$ to $60 \%$ & -0.002 & -0.10 & -0.04 & 0.01 & -0.06 \\
\hline $65 \%$ to $70 \%$ & -0.004 & -0.13 & -0.05 & -0.02 & -0.04 \\
\hline $65 \%$ to $75 \%$ & -0.003 & -0.15 & -0.07 & -0.04 & -0.03 \\
\hline $65 \%$ to $80 \%$ & -0.005 & -0.21 & -0.05 & -0.01 & -0.09 \\
\hline $65 \%$ to $85 \%$ & -0.008 & -0.21 & -0.07 & -0.04 & -0.06 \\
\hline $65 \%$ to $90 \%$ & -0.011 & -0.25 & -0.08 & -0.04 & -0.08 \\
\hline
\end{tabular}


Table 8d: based on 2007's wage structure and other explanatory variables

\begin{tabular}{|l|c|c|c|c|c|}
\hline & Gini & $90^{\text {th }} / 10^{\text {th }}$ & $75^{\text {th }} / 25^{\text {th }}$ & $90^{\text {th }} / 50^{\text {th }}$ & $50^{\text {th }} / 10^{\text {th }}$ \\
\hline $10 \%$ to $50 \%$ & -0.011 & 0.01 & 0.03 & -0.03 & 0.03 \\
\hline $20 \%$ to $50 \%$ & -0.008 & 0.08 & 0.01 & -0.01 & 0.04 \\
\hline $30 \%$ to $50 \%$ & -0.002 & 0.15 & 0.04 & 0.01 & 0.05 \\
\hline $35 \%$ to $50 \%$ & 0.002 & 0.10 & 0.02 & 0.00 & 0.04 \\
\hline $40 \%$ to $50 \%$ & 0.003 & 0.02 & 0.03 & 0.02 & 0.03 \\
\hline $45 \%$ to $50 \%$ & -0.003 & 0.04 & 0.04 & 0.03 & 0.01 \\
\hline $55 \%$ to $50 \%$ & 0.007 & 0.09 & 0.05 & 0.04 & 0.01 \\
\hline $60 \%$ to $50 \%$ & 0.004 & 0.24 & 0.07 & 0.01 & 0.05 \\
\hline $65 \%$ to $50 \%$ & 0.008 & 0.11 & 0.03 & 0.04 & 0.04 \\
\hline $70 \%$ to $50 \%$ & 0.007 & 0.21 & 0.06 & 0.04 & 0.02 \\
\hline $75 \%$ to $50 \%$ & 0.012 & 0.06 & 0.02 & 0.06 & 0.02 \\
\hline $80 \%$ to $50 \%$ & 0.009 & 0.20 & 0.05 & 0.07 & 0.03 \\
\hline $85 \%$ to $50 \%$ & 0.013 & 0.24 & 0.07 & 0.08 & 0.04 \\
\hline $90 \%$ to $50 \%$ & 0.019 & 0.30 & 0.09 & & \\
\hline
\end{tabular}

Source: CHIP 1988, 1995, 2002 and 2007 urban household surveys. 
Figure 1. Lorenz Curve of Wages in Urban China: 1988-2007
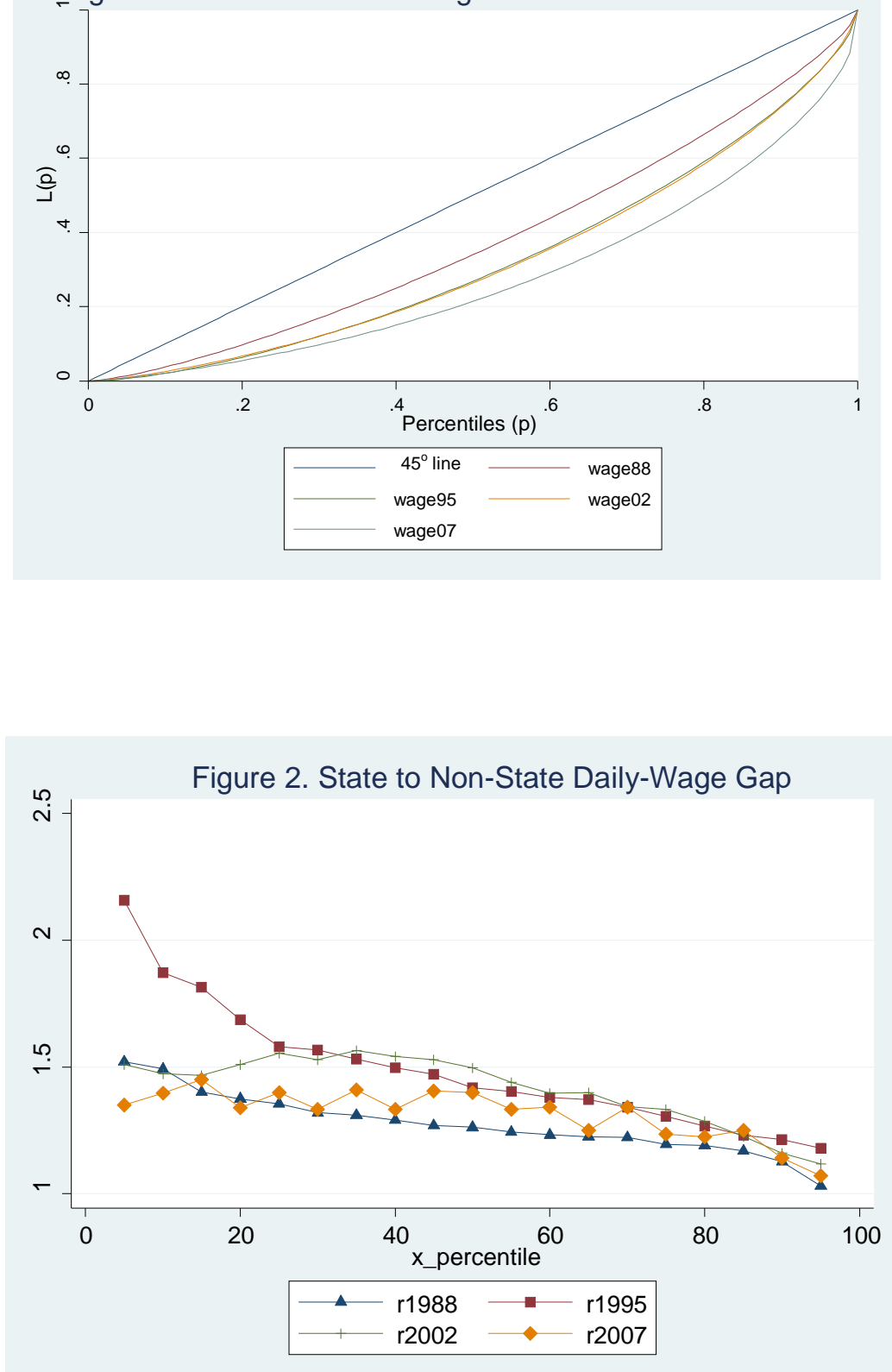

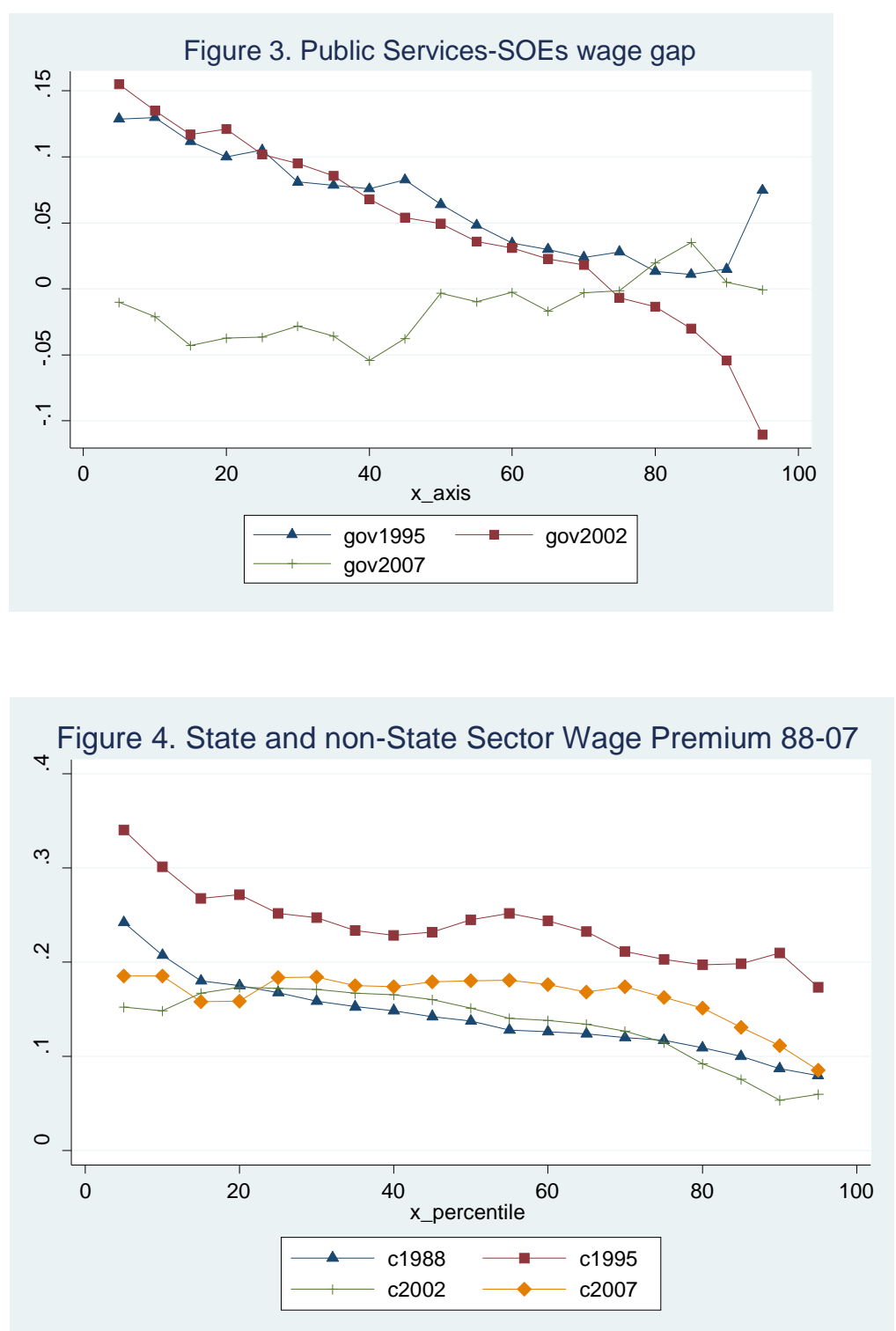